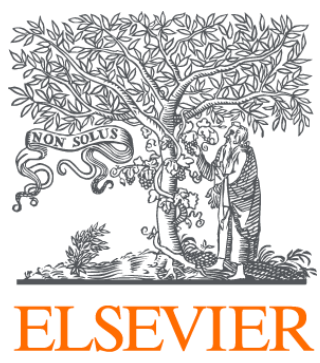

Since January 2020 Elsevier has created a COVID-19 resource centre with free information in English and Mandarin on the novel coronavirus COVID-

19. The COVID-19 resource centre is hosted on Elsevier Connect, the company's public news and information website.

Elsevier hereby grants permission to make all its COVID-19-related research that is available on the COVID-19 resource centre - including this research content - immediately available in PubMed Central and other publicly funded repositories, such as the WHO COVID database with rights for unrestricted research re-use and analyses in any form or by any means with acknowledgement of the original source. These permissions are granted for free by Elsevier for as long as the COVID-19 resource centre remains active. 


\section{Clinical and Translational Article}

\section{A Booster Dose Enhances Immunogenicity of the COVID-19 Vaccine Candidate ChAdOx1 nCoV-19 in Aged Mice}

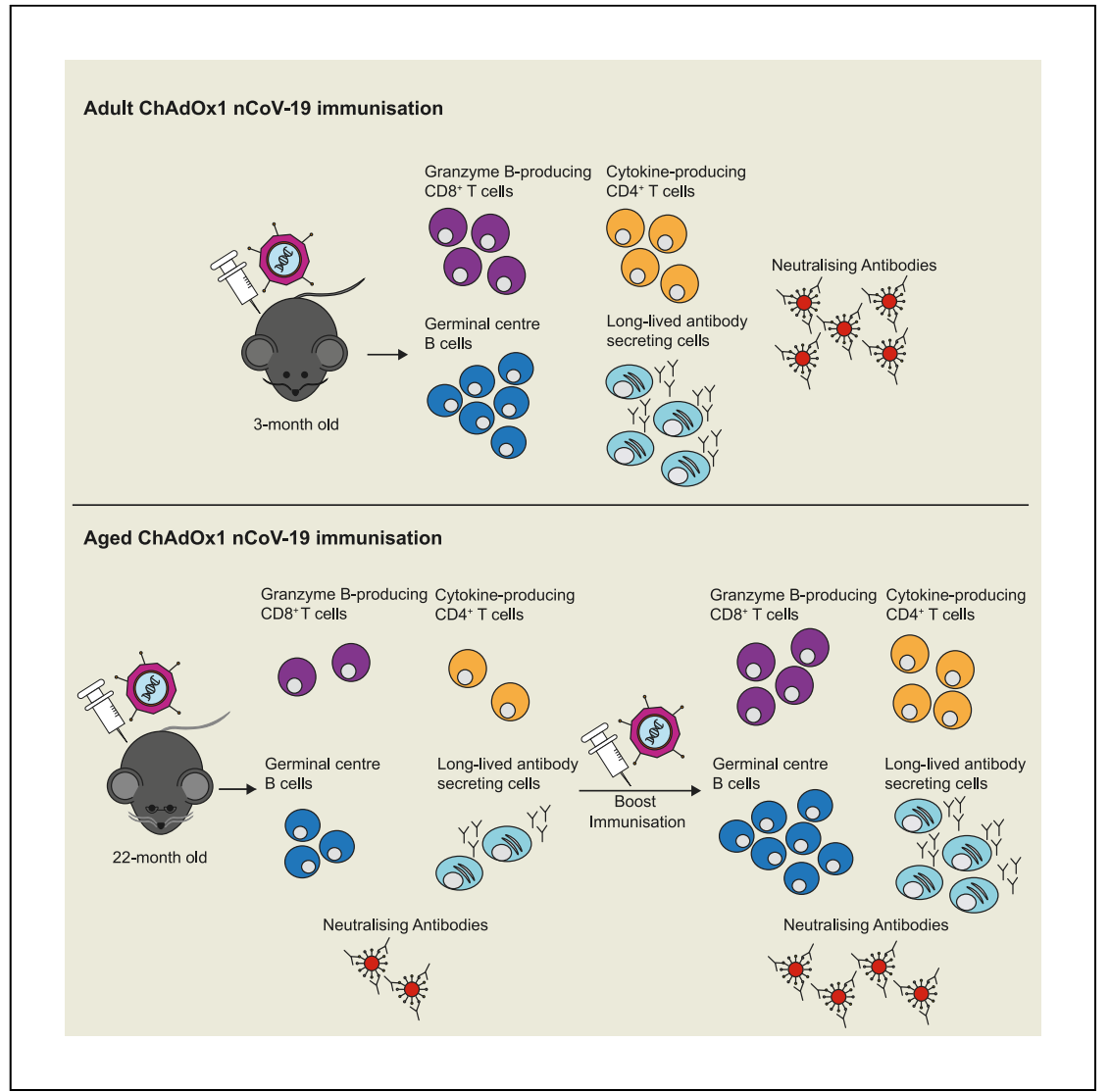

Older persons are more likely to have poor health outcomes after SARS-CoV-2 infection; therefore, they are most in need of effective COVID-19 vaccines. SilvaCayetano et al. show that a prime-boost strategy of the COVID-19 vaccine ChAdOx1 nCoV-19 enhances immunogenicity in aged mice, suggesting this as a strategy for immunizing older people.
Alyssa Silva-Cayetano, William

S. Foster, Silvia Innocentin, ..., Sarah C. Gilbert, Teresa Lambe, Michelle A. Linterman

teresa.lambe@ndm.ox.ac.uk (T.L.) michelle.linterman@babraham.ac.uk (M.A.L.)

\section{HIGHLIGHTS}

ChAdOx1 nCoV-19 induces spikespecific polyfunctional $\mathrm{CD}^{+}$and $\mathrm{CD}^{+}{ }^{+} \mathrm{T}$ cells

ChAdOx1 nCoV-19 stimulates extrafollicular plasma cell and germinal center formation

A single dose of ChAdOx1 nCoV19 induces cellular and humoral immunity in aged mice

A booster dose of ChAdOx1 nCoV-19 enhances immunogenicity in aged mice 


\title{
Clinical and Translational Article A Booster Dose Enhances Immunogenicity of the COVID-19 Vaccine Candidate ChAdOx1 nCoV-19 in Aged Mice
}

\author{
Alyssa Silva-Cayetano, 1,5 William S. Foster, ${ }^{1,5}$ Silvia Innocentin, 1,5 Sandra Belij-Rammerstorfer, ${ }^{2,6}$ \\ Alexandra J. Spencer, ${ }^{2,6}$ Oliver T. Burton, ${ }^{1}$ Sigrid Fra-Bidó, ${ }^{1}$ Jia Le Lee, ${ }^{1}$ Nazia Thakur, ${ }^{4}$ \\ Carina Conceicao, ${ }^{4}$ Daniel Wright, ${ }^{2}$ Jordan Barrett, ${ }^{2}$ Nicola Evans-Bailey, ${ }^{3}$ Carly Noble, ${ }^{3}$ Dalan Bailey, \\ Adrian Liston, ${ }^{1}$ Sarah C. Gilbert, ${ }^{2}$ Teresa Lambe, ${ }^{2,7, *}$ and Michelle A. Linterman 1,7,8,*
}

\section{SUMMARY}

Background: The spread of SARS-CoV-2 has caused a worldwide pandemic that has affected almost every aspect of human life. The development of an effective COVID-19 vaccine could limit the morbidity and mortality caused by infection and may enable the relaxation of social-distancing measures. Age is one of the most significant risk factors for poor health outcomes after SARS-CoV-2 infection; therefore, it is desirable that any new vaccine candidates elicit a robust immune response in older adults.

Methods: Here, we use in-depth immunophenotyping to characterize the innate and adaptive immune response induced upon intramuscular administration of the adenoviral vectored ChAdOx1 nCoV-19 (AZD1222) COVID-19 vaccine candidate in mice.

Findings: A single vaccination generates spike-specific Th1 cells, Th1like $\mathrm{Foxp}^{+}$regulatory $\mathrm{T}$ cells, polyfunctional spike-specific $\mathrm{CD} 8^{+}$ $T$ cells. and granzyme-B-producing CD8 effectors. Spike-specific IgG and $\mathrm{IgM}$ are generated from both the early extrafollicular antibody response and the $T$ follicular helper cell-supported germinal center reaction, which is associated with the production of virus-neutralizing antibodies. A single dose of this vaccine generated a similar type of immune response in aged mice but of a reduced magnitude than in younger mice. We report that a second dose enhances the immune response to this vaccine in aged mice.

Conclusions: This study shows that ChAdOx1 nCoV-19 induces both cellular and humoral immunity in adult and aged mice and suggests a prime-boost strategy is a rational approach to enhance immunogenicity in older persons.

Funding: This study was supported by BBSRC, Lister institute of Preventative Medicine, EPSRC VaxHub, and Innovate UK.

\section{INTRODUCTION}

The current Coronavirus Disease 2019 (COVID-19) pandemic is caused by the zoonotic severe acute respiratory syndrome coronavirus-2 (SARS-CoV-2). ${ }^{1,2}$ The pandemic has affected almost every aspect of human life and will continue to do so until effective vaccines or therapeutics are developed. SARS-CoV-2 infection is initiated when the trimeric "spike" glycoprotein on the virion surface binds angiotensin-converting enzyme 2 , allowing viral entry and initiating viral replication. ${ }^{3}$ After

\section{Context and Significance}

Effective COVID-19 vaccines will play a central role in the exit strategy from the worldwide pandemic. However, older persons often do not generate protective immunity upon vaccination due to agedependent changes in their immune system. Because older people are more likely to have poor clinical outcomes after SARS-CoV-2 infection, vaccine strategies that elicit an optimal immune response in older bodies are urgently required.

Researchers from the Babraham Institute, the Jenner Institute, and the Pirbright Institute in the UK performed pre-clinical testing of the COVID-19 vaccine candidate ChAdOx1 nCoV-19 in aged mice to assess how aging influences the immune response to this vaccine. The results show that a "primeboost" vaccine regime enhances immunogenicity in aged mice, indicating that this approach is a rational strategy for vaccinating older persons. 


\section{CellPress}

an asymptomatic incubation period, the infection can cause highly heterogenous clinical outcomes, from negligible or mild symptoms to critical disease resulting in death. ${ }^{4}$ One of the main risk factors for severe disease and death is age. ${ }^{4-6}$ Therefore, development of a successful COVID-19 vaccine should aim to be effective in older adults. ${ }^{7,8}$ However, age-related changes in the immune system mean that older individuals often do not generate protective immunity after vaccination. ${ }^{9-12}$

The effectiveness of COVID-19 vaccine candidates in older adults will ultimately be determined in clinical trials. Yet, pre-clinical studies in aged animals can be used to test alternative vaccine strategies or dosing regimens and can be used to inform clinical strategy. Despite aging occurring on different timescales in mice and people, many of the cellular and molecular changes that occur are conserved between the species. ${ }^{13,14}$ The response to vaccination is no exception ${ }^{15,16}$; after vaccination, both aged mice (>20 months old) and older humans have reduced vaccine-specific antibody formation, an impaired type I interferon (IFN) response and fewer T follicular helper cells. ${ }^{17-20}$ This impaired immune response to vaccination in older individuals has been linked with reduced protection against subsequent infection. ${ }^{9,21-23}$ Importantly, interventions that enhance the immunogenicity of vaccines in aged mice are also effective in humans. ${ }^{17,22,24,25}$

ChAdOx1 $\mathrm{nCoV}-19$ is a chimpanzee adeno (ChAd)-vectored vaccine that encodes the full-length spike protein of SARS-CoV-2. Vaccination with ChAdOx1 nCoV-19 elicits spike-specific T cells that produce IFN- $\gamma$ and anti-spike antibodies in mice, pigs, macaques, and people. ${ }^{26-28}$ Here, we demonstrate that a single dose of ChA$\mathrm{dOx} 1 \mathrm{nCoV}-19$ elicits a $\mathrm{B}$ and $\mathrm{T}$ cell response in 3-month-old adult mice, with formation of plasma cells, germinal centers, and $T$ follicular helper cells contributing to anti-spike antibody production. The development of humoral immunity is complemented by the formation of polyfunctional SARS-CoV-2 spike-specific Th1 cells and $\mathrm{CD}^{+} \mathrm{T}$ cells. In aged 22-month-old mice, a similar cellular and humoral response was observed upon vaccination, but the formation of germinal centers and spike-specific CD8 ${ }^{+} \mathrm{T}$ cells that secrete granzyme B was impaired. Administration of a second dose enhanced the germinal center response, spike-specific IgG and virus-neutralizing antibody titer, and no deficit in spike-specific granzyme-Bproducing $\mathrm{CD}^{+} \mathrm{T}$ cells was observed in aged mice. Together, this indicates that the immunogenicity of ChAdOx $1 \mathrm{nCoV}-19$ can be enhanced in older individuals through the use of a prime-boost vaccination strategy.

\section{RESULTS}

Intramuscular Immunization with ChAdOx1 nCoV-19 Activates AntigenPresenting Cells in the Iliac Lymph Node and Spleen

To map where antigen drains upon immunization, 3-month-old adult mice were immunized in the right quadriceps muscle with $20 \mathrm{~nm}$ fluorescent nanoparticles that freely drain into lymphoid organs. ${ }^{29} 24 \mathrm{~h}$ after injection, confocal microscopy revealed fluorescent nanoparticles in the medial iliac lymph node (iLN) and the spleen of all immunized mice (Figure S1A). These data suggest the iLN and spleen are sites of antigen drainage.

To characterize the early events of the immune response to ChAdOx $1 \mathrm{nCoV}-19$ vaccination, we immunized adult C57BL/6 mice and assessed the induction of IFN signaling as well as the expansion of antigen-presenting cell (APC) populations at day 1 and 2 post-immunization. At the site of immunization, expression of the type I and 2 IFN-inducible genes, Mx1 and Gbp2, respectively, was detected by day 1 in ChAdOx1 nCoV immunized mice compared to phosphate-buffered saline
${ }^{1}$ Lymphocyte Signalling and Development, Babraham Institute, Babraham Research Campus, Cambridge CB22 3AT, UK

${ }^{2}$ The Jenner Institute, University of Oxford, Old Road Campus Research Building, Roosevelt Drive, Oxford OX3 7DQ, UK

${ }^{3}$ Biological Services Unit, Babraham Institute, Babraham Research Campus, Cambridge CB22 3AT, UK

${ }^{4}$ The Pirbright Institute, Ash Road, Pirbright GU24 ONF, UK

${ }^{5}$ These authors contributed equally

${ }^{6}$ These authors contributed equally

${ }^{7}$ Senior author

¿Lead Contact

${ }^{\star}$ Correspondence:

teresa.lambe@ndm.ox.ac.uk (T.L.), michelle.linterman@babraham.ac.uk (M.A.L.)

https://doi.org/10.1016/j.medj.2020.12.006 
A
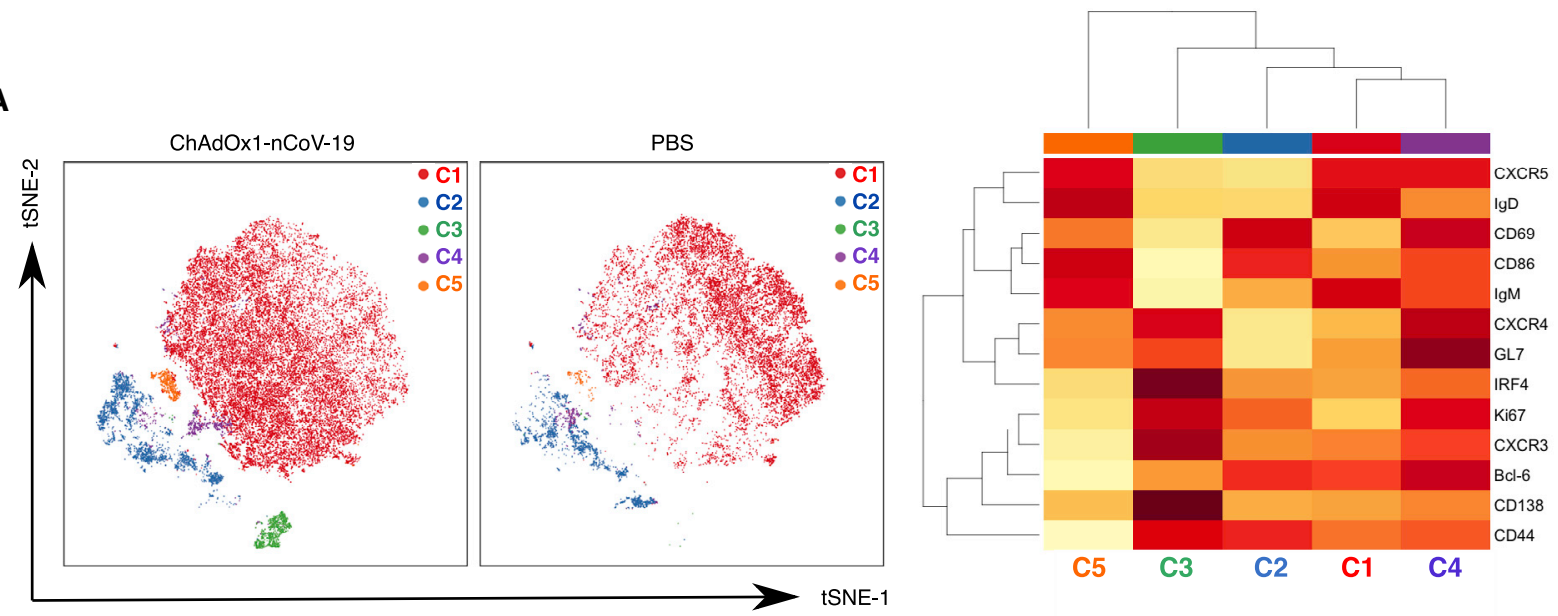

B
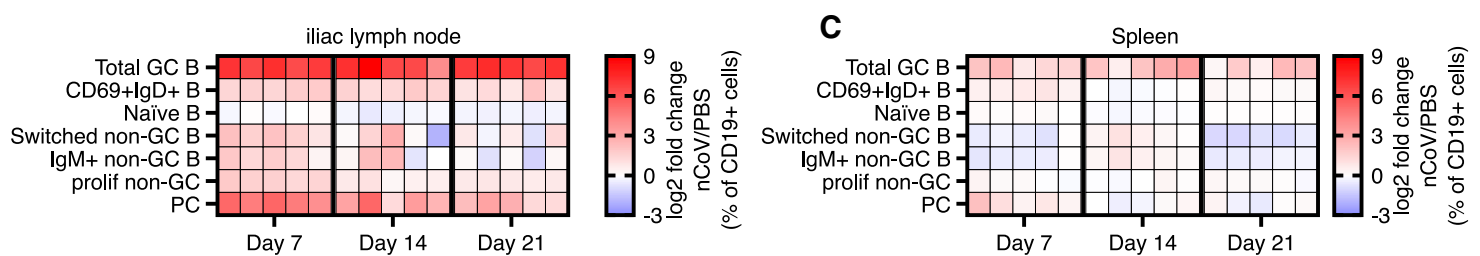

D

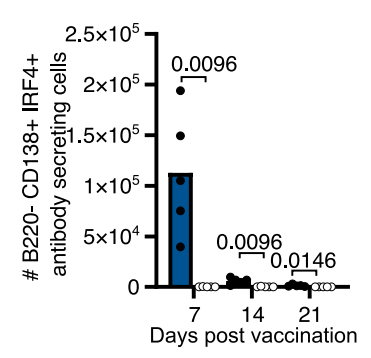

H

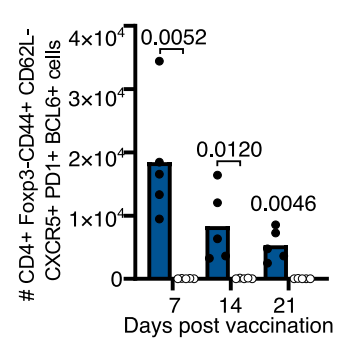

$\mathbf{E}$

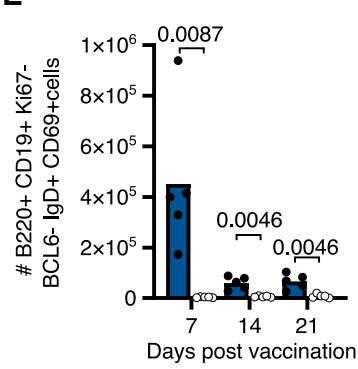

$\mathbf{F}$

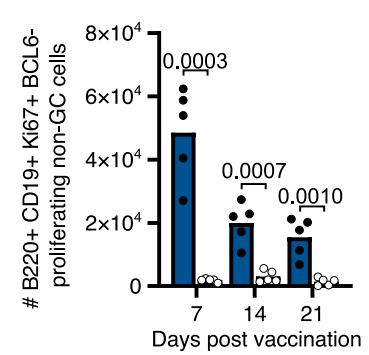

G $\square$ ChAdOx1-nCoV-19

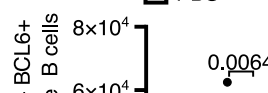

0.0064
0.0005 ठั. \#

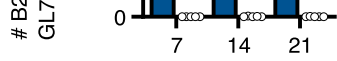
Days post vaccination

J
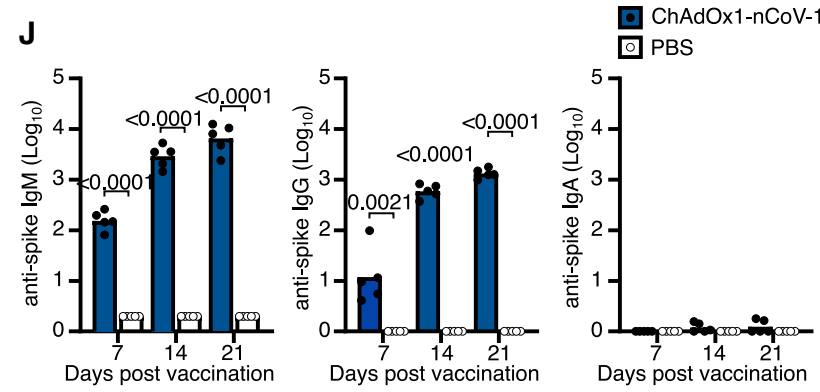

$\mathbf{K}$
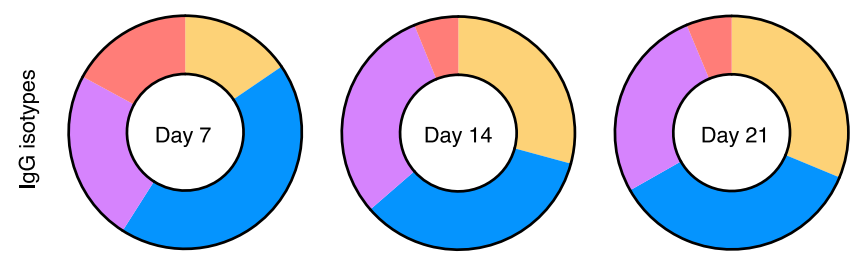

$\square \operatorname{lgG}_{1}$

$\operatorname{lgG}_{2 \mathrm{~b}}$

$\square \operatorname{lgG}_{3}$ 


\section{CellPress}

(PBS) immunized controls (Figure S1B). In the draining iLN and spleen, type 2 conventional dendritic cells (cDC2s), Langerhans cells, macrophages, and cDC1s were quantified by flow cytometry, and all subsets were activated in response to ChAdOx1 nCoV-19 (Figures S1C-S1E; gating strategy from ${ }^{30}$ ). These data demonstrate that the ChAdOx1 $\mathrm{nCoV}-19$ vaccine activates several APC populations required for the initiation of cell-mediated and humoral immunity. ${ }^{17,31,32}$

\section{ChAdOx1 nCoV-19 Immunization Stimulates B Cell Activation and Differentiation}

To assess the adaptive immune response to $\mathrm{ChAdOx} 1 \mathrm{nCoV}-19$ in detail, we used a high-dimensional flow cytometry panel that contained antibodies that recognize multiple molecules used to define different lymphocyte subsets and their activation status (Key Resources Table). Mice were immunized with either ChAdOx1 nCoV-19 or PBS, and the immune response was assessed 7, 14, and 21 days later. t-distributed stochastic neighbor embedding (tSNE) and FlowSOM analysis grouped B cells into five clusters (Figure 1A). Cluster 1 corresponded to naive B cells, which were present in both ChAdOx $1 \mathrm{nCoV}-19$ and PBS-immunized mice, and four additional clusters which were over-represented in ChAdOx1 nCoV-19-immunized mice. The clusters represent activated $B$ cells that express $\mathrm{CD} 69^{+}$(cluster 2 ) or $\mathrm{CD}_{6} 6^{+}$(cluster 5 ), a cluster of $\mathrm{CD}_{138^{+} \mathrm{IRF} 4^{+}}$antibody-secreting plasma cells (cluster 3 ) and $\mathrm{Bcl6} 6^{+} \mathrm{GL}-7^{+}$ germinal center $B$ cells (cluster 4). Manual biaxial gating of these populations (Figure $\mathrm{S} 2 \mathrm{~A}$ ) showed that $\mathrm{ChAdOx} 1 \mathrm{nCoV}-19$ immunization induced a $\mathrm{B}$ cell response in the draining lymph node and spleen (Figures $1 \mathrm{~B}$ and $1 \mathrm{C}$ ), with early B cell activation and plasma cell formation occurring in the first week after immunization, and the germinal center response persisting over the three weeks assessed (Figures 1B-1G). Formation of $\mathrm{T}$ follicular helper and $\mathrm{T}$ follicular regulatory cells accompanied the germinal center response (Figures $1 \mathrm{H}$ and $1 \mathrm{l}$ ). Antibodies binding the SARS-CoV-2 spike protein were induced by vaccination, and, as expected, the temporal induction of anti-spike $\lg M$ was faster than that of $\lg G$, and serum $\lg A$ antibodies were not observed at high titer (Figure 1J). Of note, the method of quantification does not facilitate direct comparison between IgG and IgM titer. A mix of anti-spike IgG antibody subtypes was observed, with $\lg _{2}$ and $\lg G_{1}$ subclasses persisting at later time points. At all time points, a predominantly Th1 dominant response $\left(\mathrm{lgG}_{2}\right)$ was measured (Figure $1 \mathrm{~K}$ ). The mean (and standard deviation) value for ratio of $\operatorname{lgG}_{2} /$ $\lg G_{1}$ on day 7 was 4.8 (1.4), on day 14 was $2.3(0.5)$, and on day 21 was 2.8 (1.8). This demonstrates that $\mathrm{ChAdO} \times 1 \mathrm{nCoV}-19$ immunization stimulates $\mathrm{B}$ cell activation and differentiation, culminating in the production of anti-spike antibodies.

\section{ChAdOx1 nCoV-19 Immunization Induces Th1 Cell and Th1-like Treg \\ Formation}

To investigate how ChAdOx1 nCoV-19 immunization affects $\mathrm{CD}^{+} \mathrm{T}$ cells beyond the germinal center-associated subsets, tSNE analysis followed by manual gating

Figure 1. ChAdOx1 nCoV-19 Induces a Plasma Cell and Germinal Center B Cell Response

(A) tSNE/FlowSOM analyses of CD19+ B cells from 3-month-old (3mo) mice 7 days after immunization with ChAdOx1 nCoV-19 or PBS; on the heatmap, red indicates high expression, and yellow indicates low expression.

(B and C) Heatmaps of the manually gated B cell populations indicated at 7, 14, and 21 days after immunization in the iliac lymph node (B) and spleen (C); the gating strategy for these populations is shown in Figure S2. Here, the frequency of each cell subset in each ChAdOx1 nCoV-19-immunized mouse has been expressed as the log2 fold change over the average frequency in PBS-immunized mice $(n=5)$.

(D-J) Bar charts showing the total number of plasma cells (D), CD69 IgD ${ }^{+}$B cells (E), proliferating non-germinal center B cells (F) and germinal center B cells $(G)$ at the indicated time points after immunization. Number of T follicular helper (H) and T follicular regulatory cells (I) at the indicated time points post-immunization. Serum anti-spike $\lg M, \lg G$, and $\lg A(\mathrm{~J})$ antibodies 7, 14, and 21 days after immunization.

(K) Pie charts indicating the mean abundance of each IgG antibody subclass in the serum at the indicated time points after immunization.

In (D)-(J), the bar height corresponds to the mean and each circle represents one biological replicate. $p$ values are calculated using a Student's $t$ test with Holm-Sidak multiple testing correction; for ELISA, data analyses were done on log transformed values. 
A
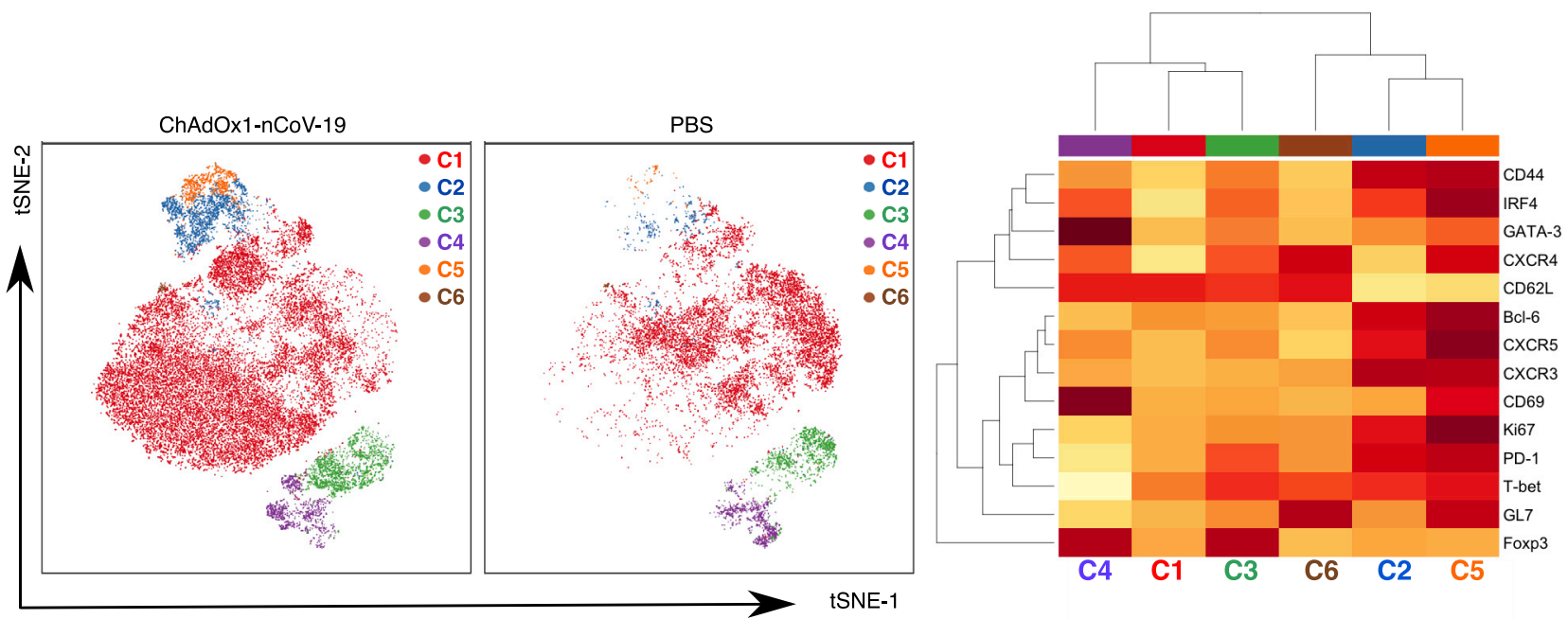

B
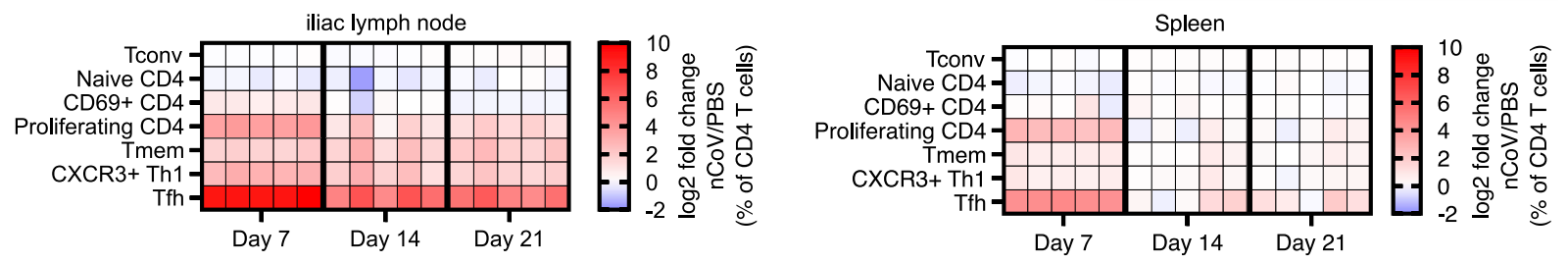

C
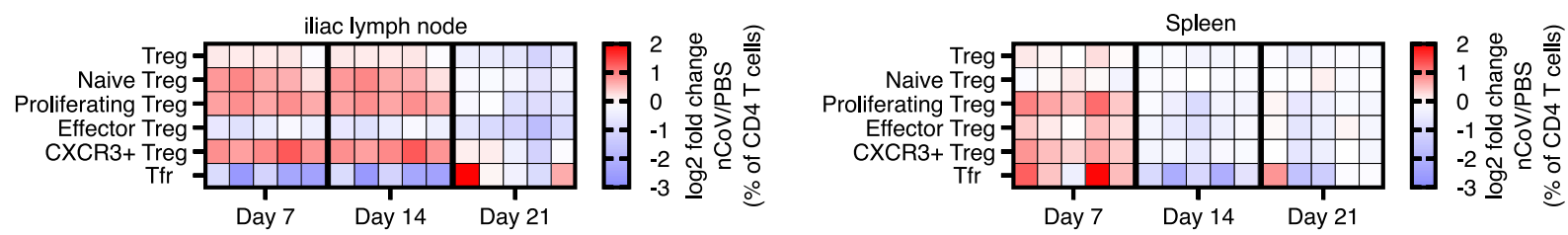

D

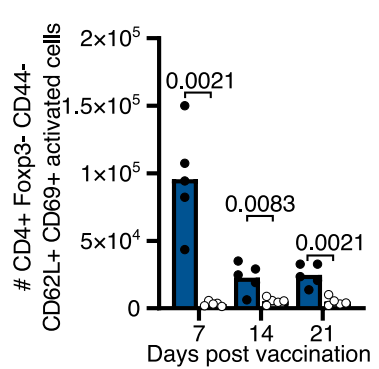

H

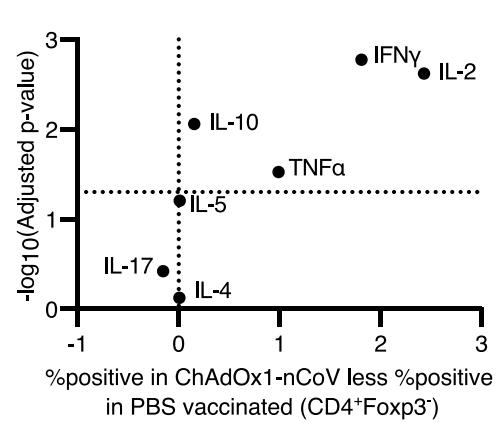

E
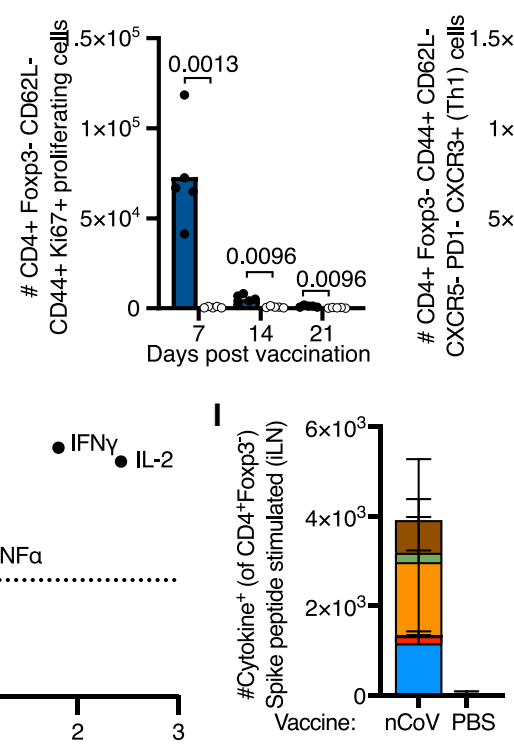

$\mathbf{F}$
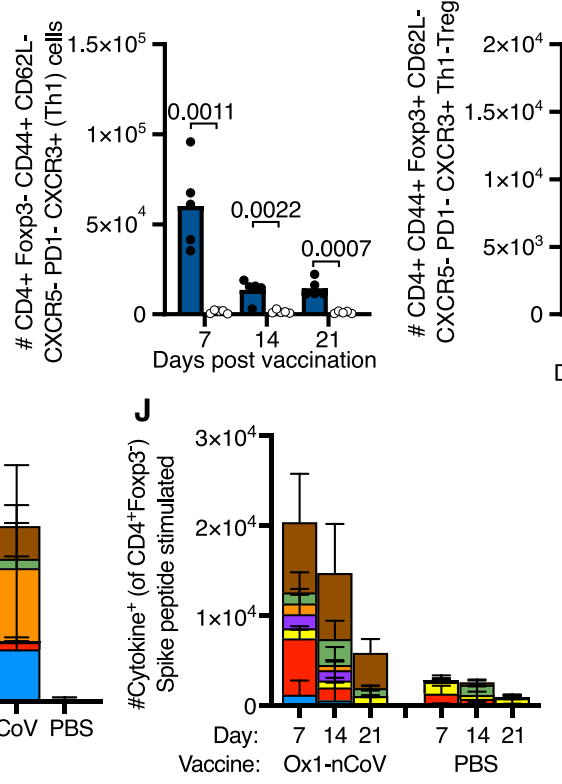

G ChAdOx1-nCoV-19 宁 回 PBS

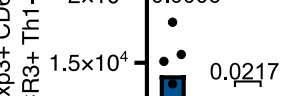

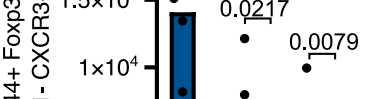

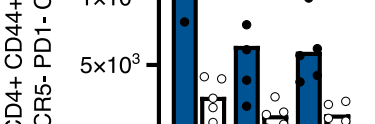
Days post vaccination $\square \mathrm{IFNY}^{+}$ ए $\mathrm{L}_{-2}{ }^{+}$ $\mathrm{TNFa}^{+}$ IFNy ${ }^{+} \mathrm{IL}-2^{+}$

ए $\mathrm{FNy}^{+} \mathrm{TNFa}^{+}$

$\mathrm{TNFa}^{+} \mathrm{IL}-2^{+}$

ש IFNy ${ }^{+} \mathrm{TNFa}^{+} \mathrm{IL}-2^{+}$

.




\section{CellPress}

was performed (Figures 2A and 2B; Figures S2B and S2C). tSNE/FlowSOM clustering showed that vaccination induced populations of $\mathrm{T}$ cells that express markers associated with $\mathrm{T}$ follicular helper cells (cluster 5), Th1 cells (cluster 2), Tbet-expressing Th1-like Tregs (cluster 3), and CD69+-activated Treg cells (cluster 4) (Figure 2A). The conventional $\mathrm{CD}^{+}{ }^{+} \mathrm{T}$ cell response to $\mathrm{ChAdO} \times 1 \mathrm{nCoV}-19$ was characterized by early activation and proliferation, as well as the formation of $\mathrm{CXCR}^{+}$Th1 cells (Figures 2A-2F). The Foxp ${ }^{+}$regulatory $T$ cell response was characterized by early expression of $\mathrm{Ki67}$, indicative of proliferation, and the differentiation of $\mathrm{CXCR}^{+}$ Th1-like cells (Figures $2 \mathrm{C}$ and $2 \mathrm{G}$ ). To further characterize $\mathrm{CD} 4^{+} \mathrm{T}$ cell responses after vaccination, cells from the iLN were restimulated with $\mathrm{PdBu}$ /ionomycin and cytokine production was assessed. IL-2, TNF- $\alpha$, IL-10, and IFN- $\gamma$ were induced by cells isolated from animals that had been $\mathrm{ChAdO} \times 1 \mathrm{nCoV}-19$ vaccinated, with no difference observed in Th17-associated IL-17 or the Th2-associated cytokines IL-4 and IL5 (Figure 2H; Figure S3A-S3C). The spike specificity of this Th1-associated response in the draining lymph node was confirmed by restimulation of cells with peptide pools from SARS-CoV-2 spike protein (Figure 2I). In the spleen, spike-specific IL-2, $\mathrm{TNF}-\alpha$, and IFN- $\gamma$-producing $\mathrm{CD} 4{ }^{+} \mathrm{T}$ cells were observed, with triple producers persisting 21-days after immunization (Figure 2J, Figure S3D), consistent with previous work. ${ }^{26}$ Therefore, ChAdOx $1 \mathrm{nCoV}-19$ vaccination induces an early formation of Th1 cells and Th1-like Treg cells accompanied by the induction of spike-specific Th1skewed cytokine-secreting cells.

\section{ChAdOx1 nCoV-19 Induces a CD8 ${ }^{+} \mathrm{T}$ Cell Response}

tSNE analysis of $\mathrm{CD}^{+} \mathrm{T}$ cells from the iLNs of ChAdOx1 nCoV-19-immunized and PBS control mice revealed distinct clustering 7 days after immunization. There were five $\mathrm{CD}^{+} \mathrm{T}$ cell clusters that were more abundant in $\mathrm{ChAdO} \times 1 \mathrm{nCoV}$-19-immunized mice, than in PBS-immunized animals. Cluster 2 contains markers consistent with a CXCR5 ${ }^{+}$follicular CD8 cell population, cluster 3 is characterized by CXCR3 expression a marker of tissue homing, clusters 4 and 5 expresses CD69 and CD62L consistent with CD8 cells at an early stage of activation, and cluster 6 expresses high levels of CXCR4 a chemokine receptor that facilitates bone-marrow localization of $\mathrm{CD}^{+} \mathrm{T}$ cells (Figure $3 \mathrm{~A}$ ). Together, this highlights that a diverse array of $\mathrm{CD}^{+} \mathrm{T}$ cell subsets are induced by $\mathrm{ChAdO} \times 1 \mathrm{nCoV}-19$. In order to understand how the response evolves over time, manual gating of different $\mathrm{CD} 8^{+} \mathrm{T}$ cell populations (Figure S2D), including those identified in the tSNE analysis, was done on samples taken 7, 14, and 21 days after immunization. In the iLN and spleen, the CD8 ${ }^{+}$ $\mathrm{T}$ cell response to $\mathrm{ChAdOx} 1 \mathrm{nCoV}-19$ was characterized by an increase in $\mathrm{Ki67}$ expression, the upregulation of the activation markers CD69, CXCR3, and PD-1, as well as the formation of $\mathrm{CD} 44^{+} \mathrm{CD} 62 \mathrm{~L}^{-}$antigen-experienced $\mathrm{T}$ cells (Figures

Figure 2. ChAdOx1 nCoV-19 Induces a Th1-Dominated CD4 Cell Response

(A) tSNE/FlowSOM analyses of CD4 ${ }^{+}$T cells from 3-month-old (3mo) mice 7 days after immunization with ChAdOx1 nCoV-19 or PBS; on the heatmap, red indicates high expression, and yellow indicates low expression.

(B and C) Heatmaps of the manually gated CD4 ${ }^{+}$Foxp $3^{-}(B)$ and Foxp $3^{+} C D 4^{+}(C)$ T cell populations indicated at 7,14 , and 21 days after immunization in the iliac lymph node (right) and spleen (left), the gating strategy for these populations is shown in Figure S2. Here, the frequency of each cell subset in each ChAdOx1 nCoV-19-immunized mouse has been expressed as the log2 fold change over the average frequency in PBS-immunized mice ( $\mathrm{n}=5$ )

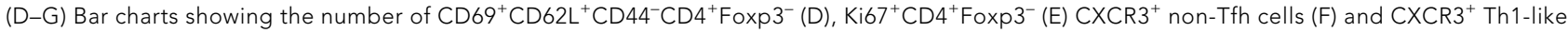
Treg cells (G) $C D 4^{+}$cells in the iliac lymph node of ChAdOx1 nCoV-19 or PBS-immunized mice, at the indicated time points post-immunization. (H) Analysis of cytokine production $6 \mathrm{~h}$ after PdBu/ionomycin stimulation of iliac lymph node cells from 3-month-old mice 7 days after immunization with ChAdOx1 nCoV-19 or PBS.

(I and J) Stacked bar plots show the number of CD4 ${ }^{+}$Foxp $3^{-}$cells singly or co-producing IFN- $\gamma$, IL-2, or TNF- $\alpha$ in the iLN 7 days after immunization (I) or spleen at the days post-immunization (J); $6 \mathrm{~h}$ after restimulation with SARS-CoV-2 peptide pools, each bar segment represents the mean and the error bars the standard deviation.

In (D)-(G), the bar height corresponds to the mean and each circle represents one biological replicate. $p$ values are calculated using a Student's t test with Holm-Sidak multiple testing correction. 
A
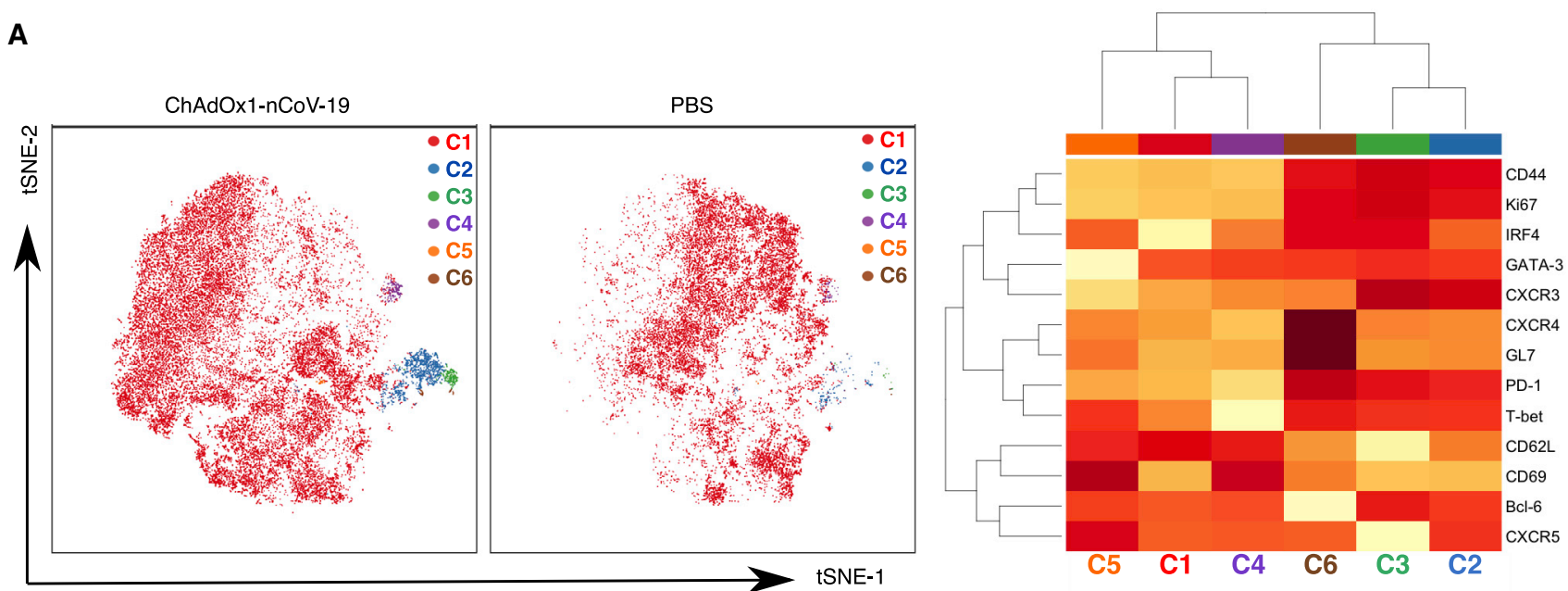

B
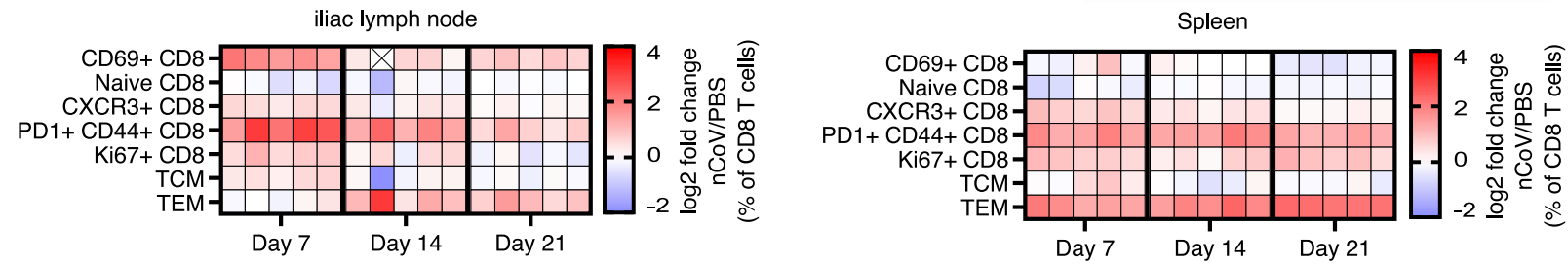
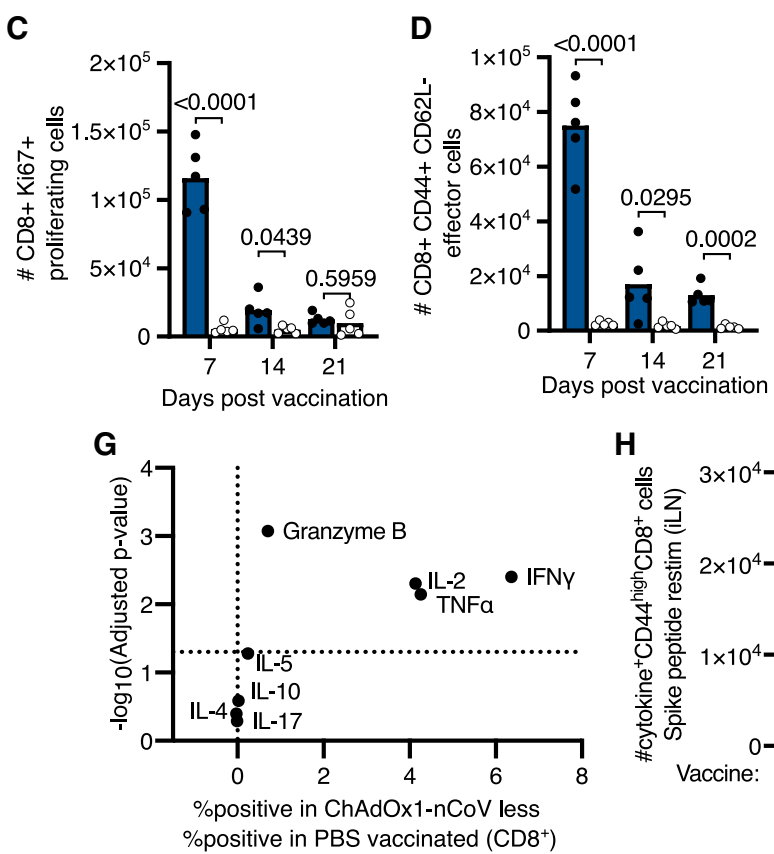

H

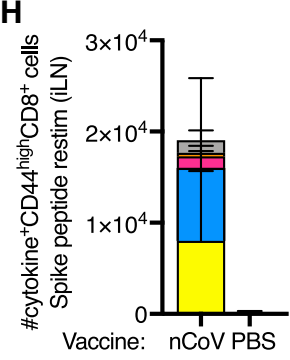

E

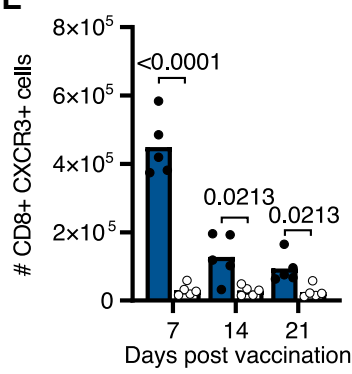

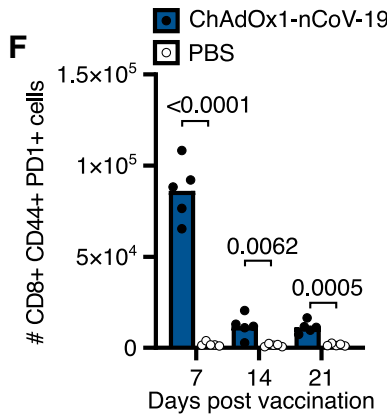

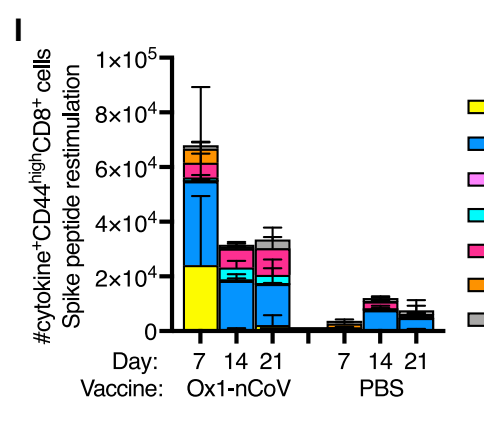

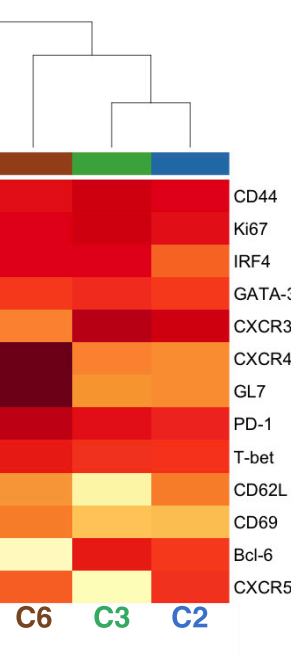
Granzyme B ${ }^{+}$

$\square$ IFNy ${ }^{+}$

$\square \mathrm{IFNY}{ }^{+} \mathrm{IL}-2^{+}$

IFNY ${ }^{+} \mathrm{IL}-2^{+} \mathrm{TNFa}^{+}$

$\square \mathrm{IFN \gamma}+\mathrm{TNFa}^{+}$

$\longrightarrow \mathrm{IL}-2^{+}$

$\square \mathrm{TNFa}^{+}$

Figure 3. ChAdOx1 nCoV-19 Induces a CD8 T Cell Response

(A) tSNE/FlowSOM analyses of CD8 ${ }^{+} \mathrm{T}$ cells from 3-month-old (3mo) mice 7 days after immunization with ChAdOx1 nCoV-19 or PBS; on the heatmap red indicates high expression, and yellow indicates low expression.

(B) Heatmap of the manually gated CD8 T cell populations indicated at 7, 14, and 21 days after immunization in the iliac lymph node and spleen; the gating strategy for these populations is shown in Figure S2. The frequency of each cell subset in each ChAdOx1 nCoV-19-immunized mouse has been expressed as the log2 fold change over the average frequency in PBS-immunized mice $(n=5)$. Crossed boxes indicate that there were none of that cell type for that mouse. 


\section{CellPress}

\section{Clinical and Translational Article}

3B-3F). To characterize the overall production of granzyme $\mathrm{B}$ and cytokines by $\mathrm{CD} 8^{+}$ $T$ cells 7 days after vaccination, cells from the iLN were restimulated with $\mathrm{PdBu} /$ ionomycin. There was a significant production of granzyme B, IL-2, TNF- $\alpha$, and IFN- $\gamma$ in ChAdOx1 nCOV-19-vaccinated mice compared to PBS-immunized mice (Figure 3G). The spike specificity of cytokine-producing cells in the draining lymph node was confirmed by restimulation with SARS-CoV-2 peptide pools (Figure $3 \mathrm{H}$ ). Restimulation of splenocytes with SARS-CoV-2 spike protein peptide pools from SARS-CoV-2 showed that spike-specific cytokine-producing $\mathrm{CD}^{+} \mathrm{T}$ cells form in response to immunization (Figure 31; Figures S4A and S4B). Spike-specific granzyme-B-producing $\mathrm{CD}^{+} \mathrm{T}$ cells formed early and tended not to co-produce cytokines (Figure 3l). Both single and multiple cytokine-producing spike-specific cells formed at all time points, with TNF- $\alpha$ and IFN- $\gamma$ being the dominant cytokines expressed (Figure 3I; Figure $\mathrm{S} 4 \mathrm{C}$ ). With this dosing regimen, these data demonstrate that $\mathrm{ChAdOx} 1$ $\mathrm{nCoV}-19$ stimulates a spike-specific $\mathrm{CD}^{+} \mathrm{T}$ cell response that peaks around the first week after vaccination.

\section{A Prime-Boost Strategy Corrects Dysregulated CD8 T Cell Priming in Aged Mice}

To assess the $\mathrm{CD}^{+} \mathrm{T}$ cell response to ChAdOx1 $\mathrm{nCoV}-19$ immunization in the context of aging, we immunized 3- and 22-month-old mice and enumerated the $\mathrm{CD}^{+} \mathrm{T}$ cell types altered by vaccination (in Figure 3) 9 days after immunization (Figure $4 \mathrm{~A}$ ). In the draining iLN, CD8 ${ }^{+} \mathrm{T}$ cells from aged mice expressed markers of activation and proliferation in response to $\mathrm{ChAdOx} 1 \mathrm{nCoV}-19$. Unlike in younger adult mice, the frequency of $\mathrm{CXCR}^{+}$cells or antigen-experienced cells did not increase in aged mice, compared to the PBS-vaccinated group (Figures 4B-4D). At this early time point, the frequency of central memory $T$ cells was not altered in either younger adult or aged mice by ChAdOx1 nCoV-19 vaccination (Figure 4E). In the spleen, fewer $\mathrm{Ki}_{6}{ }^{+} \mathrm{CD}^{+} \mathrm{T}$ cells were observed in aged mice after $\mathrm{ChAdOx} 1 \mathrm{nCoV}-19$ vaccination, compared to younger adult mice (Figure 4F). The formation of spike-specific $\mathrm{CD}^{+} \mathrm{T}$ cells was assessed by restimulating splenocytes with SARS-CoV-2 spike protein peptide pools. Aged mice had a near absence of spike-specific granzyme-Bproducing $\mathrm{CD}^{+} \mathrm{T}$ cells, but production of IFN- $\gamma$ and TNF- $\alpha$ was not significantly impaired compared to younger mice (Figure $4 \mathrm{G}$ ). Despite a trend to lower cytokine production by $\mathrm{CD}^{+} \mathrm{T}$ cells in aged mice, the proportion of polyfunctional spike-specific $\mathrm{CD}^{+} \mathrm{T}$ cells was not significantly diminished in aged mice after ChAdOx1 $\mathrm{nCoV}-19$ vaccination (Figure $4 \mathrm{H}$ ). This demonstrates that a single dose of ChAdOx1 $\mathrm{nCoV}-19$ induces an altered $\mathrm{CD}^{+} \mathrm{T}$ cell response in aged mice characterized primarily by a failure to form spike-specific granzyme-B-producing effector cells.

To determine whether a second dose could improve this response, we administered a booster dose of ChAdOx1 nCoV-19 1 month after prime immunization (Figure 4I). Nine days after boost, an increase in $\mathrm{Ki} 67^{+} \mathrm{CD} 8^{+} \mathrm{T}$ cells was not observed in the draining iLN (Figure $4 \mathrm{~J}$ ), possibly due to the kinetics of the secondary response being faster than the primary. A significant increase in $\mathrm{CXCR}^{+} \mathrm{CD}^{+} \mathrm{T}$ cells and

$(\mathrm{C}-\mathrm{F})$ Bar charts showing the number of $\mathrm{Ki} 67^{+}(\mathrm{C})$, antigen-experienced $\mathrm{CD} 44^{+} \mathrm{CD} 62 \mathrm{~L}^{-}(\mathrm{D}), \mathrm{CXCR} 3^{+}(\mathrm{E})$, and PD- $1^{+} \mathrm{CD} 44^{+}(\mathrm{F}) \mathrm{CD} 8$ cells in the iliac lymph node of $\mathrm{ChAdO} \times 1 \mathrm{nCoV}-19$ or PBS-immunized mice, at the indicated time points post-immunization.

(G) Analysis of cytokine production $6 \mathrm{~h}$ after PdBu/ionomycin stimulation of iliac lymph node cells from 3-month-old mice 7 days after immunization with ChAdOx1 nCoV-19 or PBS.

( $\mathrm{H}$ and I) Stacked bar plots show the number of $\mathrm{CD} 8^{+}$cells singly or co-producing Granzyme B, IFN- $\gamma$, IL-2, or TNF- $\alpha 6$ h after restimulation with SARSCoV-2 peptide pools, in the iLN 7 days after immunization (H) or spleen 7, 14, and 21 days after immunization (I); each bar segment represents the mean and the error bars the standard deviation.

In (C)-(F), the bar height corresponds to the mean, and each circle represents one biological replicate. p values are calculated using a Student's t test with Holm-Sidak multiple testing correction. 
A

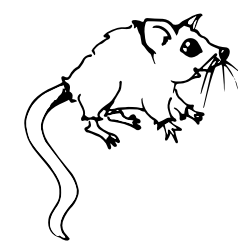

B

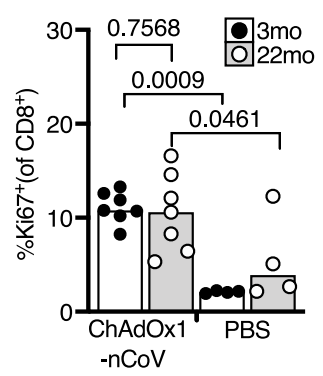

$\mathbf{F}$

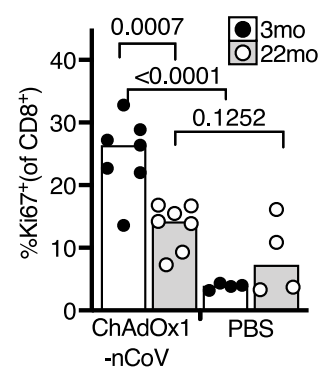

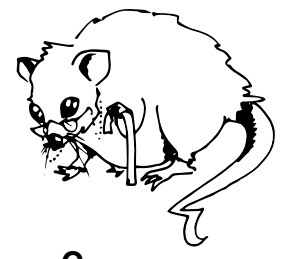

C

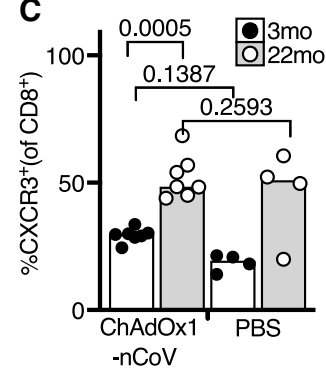

G

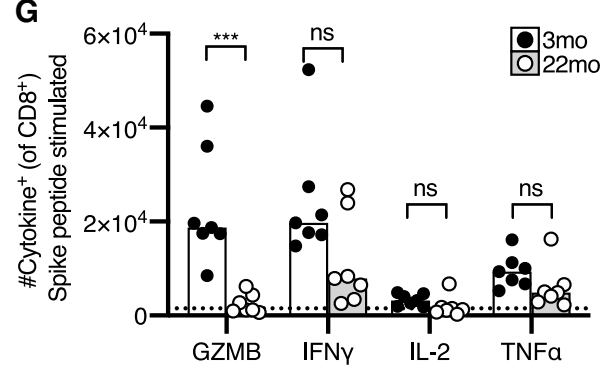

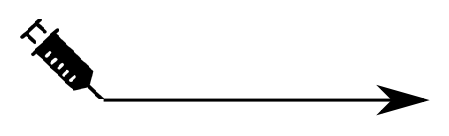

9 days post-prime
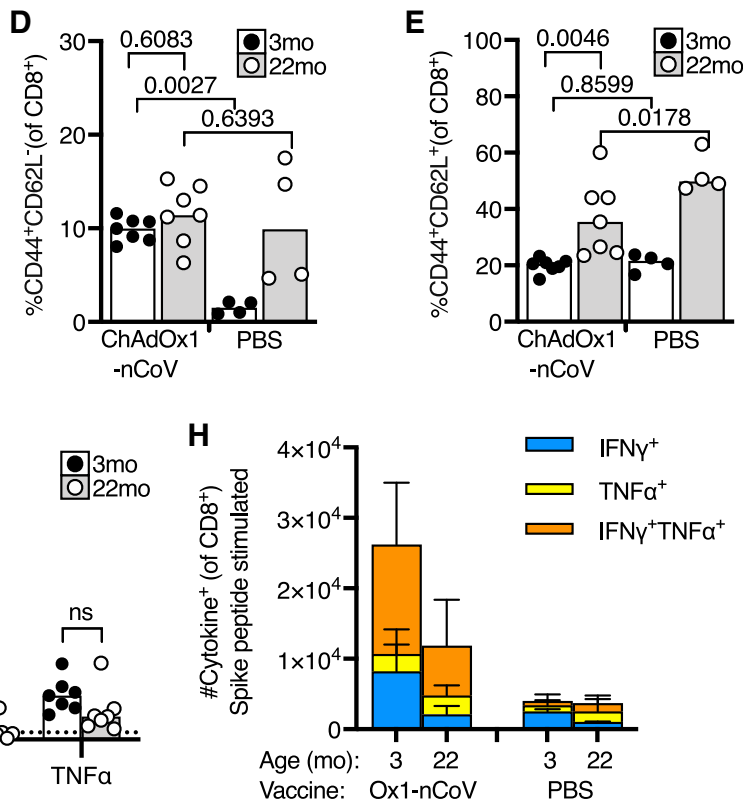

I

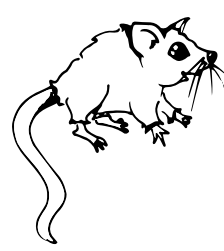

J

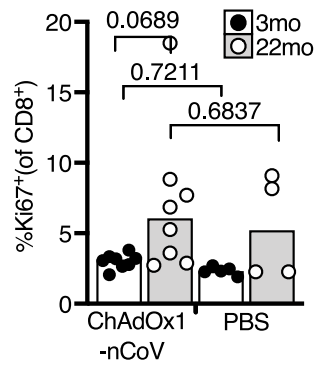

N

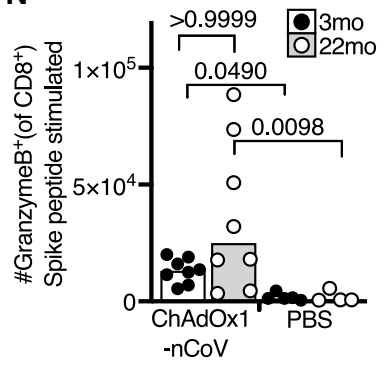

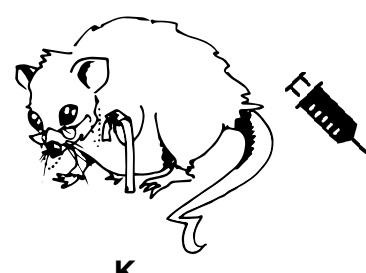

$\mathbf{K}$

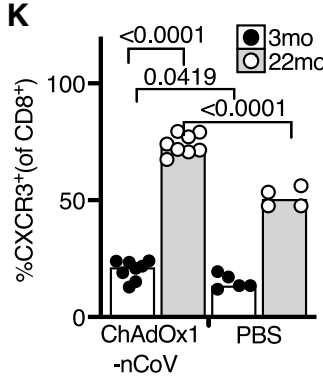

O

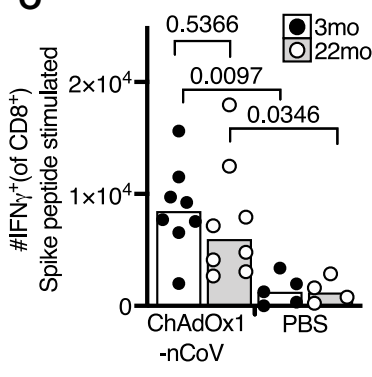

9 days post-boost post-prime

$\mathbf{L}$

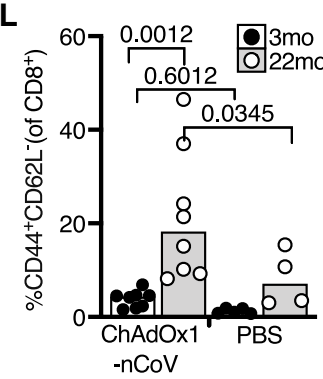

$\mathbf{P}$

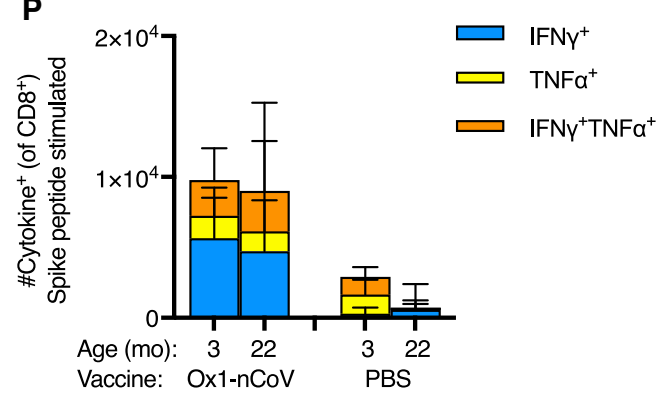




\section{CellPress}

\section{Clinical and Translational Article}

antigen-experienced cells was observed in aged mice after boost, with no change in the proportion of central memory cells in either age group (Figures 4K-4M). Assessment of spike-specific T cells showed that the booster dose of ChAdOx1 nCoV-19 rescued the production of granzyme-B-producing $\mathrm{CD}^{+} \mathrm{T}$ cells in aged mice (Figure $4 \mathrm{~N})$. IFN- $\gamma$ production and cytokine polyfunctionality were similar to that following prime immunization (Figures $4 \mathrm{O}$ and 4P). This demonstrates that ChAdOx1 nCoV-19 is immunogenic in aged mice, and a booster dose can correct the age-dependent defect in the formation of spike-specific granzyme-B-producing $\mathrm{CD}^{+} \mathrm{T}$ cells.

\section{Prime-Boost Enhances the CD4 ${ }^{+} \mathrm{T}^{\mathrm{C}}$ Cell Response to ChAdOx1 nCoV-19 in Aged Mice}

Nine days after primary immunization of aged mice (Figure $5 \mathrm{~A}$ ), an increase in $\mathrm{Ki} 67^{+} \mathrm{CD}^{+} \mathrm{T}$ cells and CXCR3-expressing Th1 cells was observed in the draining lymph node of ChAdOx1 nCoV-19-immunized mice compared to PBS-immunized control mice (Figures $5 B$ and $5 C$ ). This was accompanied by an increase in the frequency of Th1-like Tregs in both adult and aged mice (Figure 5D). An increased frequency of these cell types was likewise observed in the spleen in response to ChAdOx1 nCoV-19 immunization in both adult and aged mice (Figures 5E-5G). It is notable that, by these measurements, the response in aged mice is comparable to that in younger adults. The spike-specific $C D 4^{+} \mathrm{T}$ cell response was assessed by restimulating splenocytes with SARS-CoV-2 spike protein peptide pools. As in young mice (Figure 2), the response in aged mice to ChAdOx1 nCoV-19 was Th1 dominated; however, there were fewer spike-specific cytokine-producing cells in aged mice 9 days after a single immunization ( $p<0.001$, Figures $5 \mathrm{H}$ and $5 \mathrm{l}$ ).

A booster dose of ChAdOx $1 \mathrm{nCoV}-19$ administered 1 month after prime (Figure $5 \mathrm{~J}$ ) stimulated Ki67 expression and the formation of $\mathrm{CXCR}^{+} \mathrm{CD} 44^{+}$Th1 cells but not $\mathrm{CXCR}^{+}$Th1-like Treg cells in the draining lymph node of aged mice (Figures $5 \mathrm{~K}_{-}$ $5 \mathrm{M})$. In the spleen, the booster dose did not enhance the frequency of $\mathrm{Ki67} 7^{+}$ $\mathrm{CD}^{+} \mathrm{T}$ cells or the formation of $\mathrm{CXCR}^{+}$conventional or regulatory $\mathrm{T}$ cells in adult or aged mice (Figures $5 \mathrm{~N}-5 \mathrm{P}$ ). In contrast to the response to primary immunization, the number of spike-specific cytokine-producing cells was comparable in adult and aged mice after booster immunization (Figures $5 \mathrm{Q}$ and $5 \mathrm{R}$ ). Together, this indicates

Figure 4. A Prime-Boost Strategy Enhances the CD8 T Cell Response to ChAdOx1 nCoV-19 in Aged Mice

(A) Cartoon of prime immunization strategy.

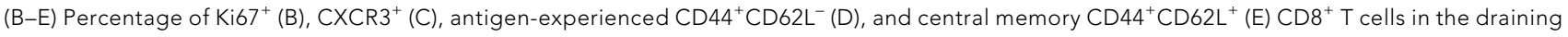
iliac lymph node from 3-month-old (3mo) or 22-month-old (22mo) mice 9 days after immunization with ChAdOx1 nCoV-19 or PBS.

(F) Percentage of proliferating Ki67 $7^{+}$splenic $\mathrm{CD} 8^{+} \mathrm{T}$ cells in 3-month-old (3mo) or 22-month-old (22mo) mice 9 days after immunization with ChAdOx1 nCoV-19 or PBS

( $\mathrm{G}$ and $\mathrm{H}$ ) Number of $\mathrm{CD} 8^{+}$T cells producing granzyme B (GZMB), IFN- $\gamma$, IL-2, or TNF- $\alpha 6 \mathrm{~h}$ after restimulation with SARS-CoV-2 peptide pools in (G), and the number of single and double cytokine-producing $C D 8^{+}$T cells are represented in stacked bar charts. Spleen cells are taken from 3-month-old (3mo) or 22-month-old (22mo) mice 9 days after immunization with ChAdOx1 nCoV-19 or PBS.

(I) Cartoon of prime-boost immunization strategy.

$(\mathrm{J}-\mathrm{M})$ Percentage of $\mathrm{Ki}^{+}(\mathrm{J}), \mathrm{CXCR}^{+}(\mathrm{K})$, antigen-experienced $\mathrm{CD}_{4} 4^{+} \mathrm{CD} 2 \mathrm{~L}^{-}(\mathrm{L})$, and central memory $\mathrm{CD}_{4}{ }^{+} \mathrm{CD} 62 \mathrm{~L}^{+}(\mathrm{M}) \mathrm{CD}^{+} \mathrm{T}_{\mathrm{cells}}$ in the draining iliac lymph node from 3-month-old or 22-month-old mice 9 days after immunization with ChAdOx1 nCoV-19 or PBS

(N-P) Percentage of proliferating Ki67 $7^{+}$splenic CD8 + T cells in 3-month-old or 22-month-old mice 9 days after immunization with ChAdOx1 nCoV-19 or PBS. Number of $\mathrm{CD}^{+}$cells producing Granzyme B (N) or IFN- $\gamma(\mathrm{O}) 6 \mathrm{~h}$ after restimulation with SARS-CoV-2 peptide pools in (P), and the number of single and double cytokine-producing $\mathrm{CD}^{+} \mathrm{T}$ cells are represented in stacked bar charts. Spleen cells are taken from 3-month-old or 22-month-old mice 9 days after immunization with ChAdOx1 nCoV-19 or PBS.

The bar height in B-G, J-O corresponds to the median and each circle represents one biological replicate. In (H), (P), each bar segment represents the mean and the error bars the standard deviation. The Shapiro-Wilk normality test was used to determine whether the data are consistent with a normal distribution, followed by either an ordinary one-way ANOVA test for data with a normal distribution or a Kruskal-Wallis test for non-normally distributed data alongside a multiple comparisons test. Data are representative of two independent experiments ( $n=4-8$ per group/experiment). 
A

B
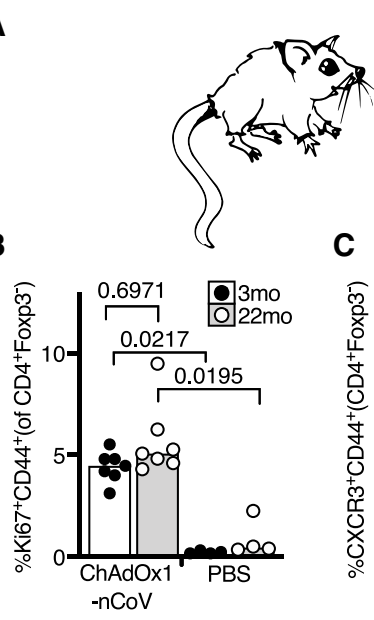

$\mathbf{F}$

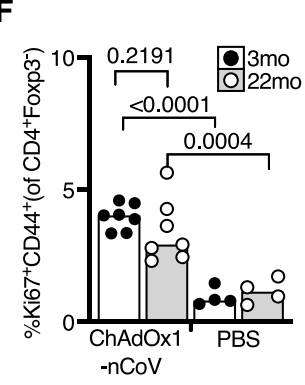

C
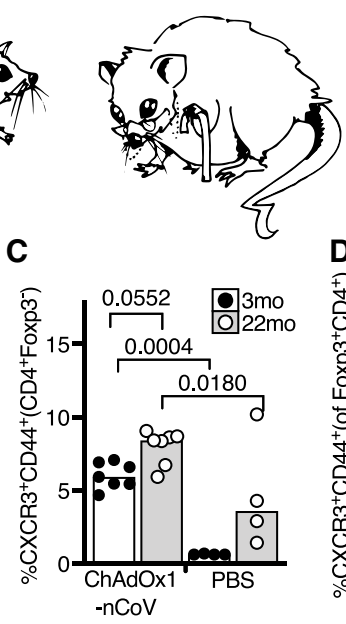

G

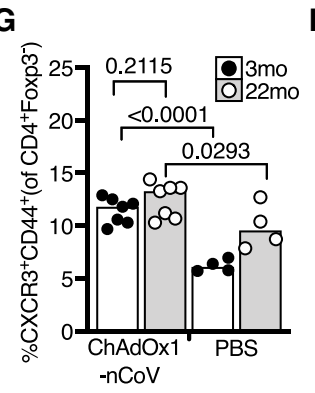

H

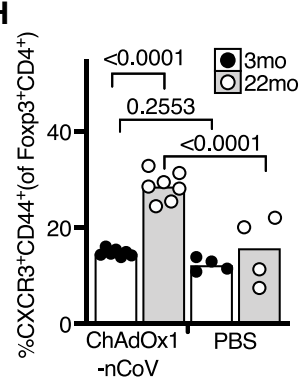

D 旁 $30-\frac{0.0042}{\frac{0.0042}{0}}$
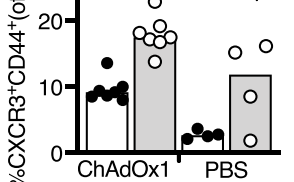

$\stackrel{\substack{\text { ChAdOx1 } \\-n \mathrm{CoV}}}{\circ}$
9 days post-prime

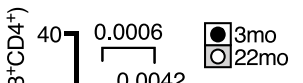

E

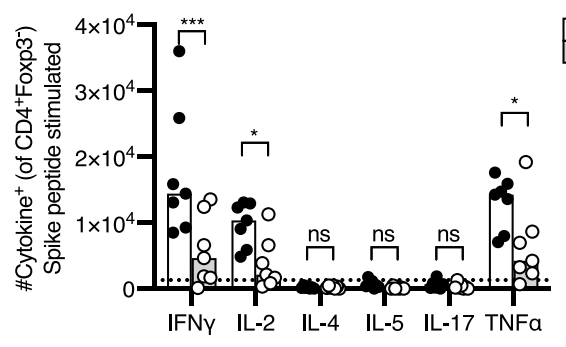

1

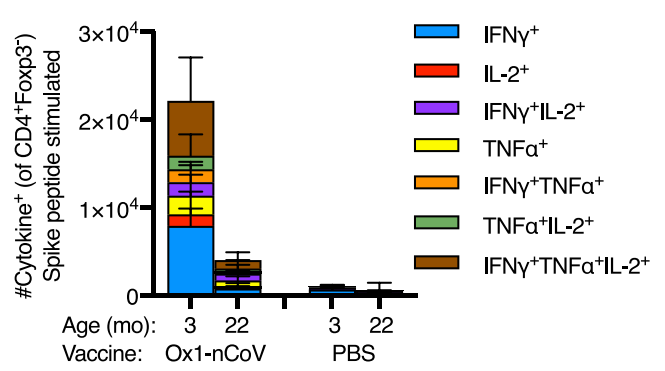

门

\section{.}

\section{年}

K
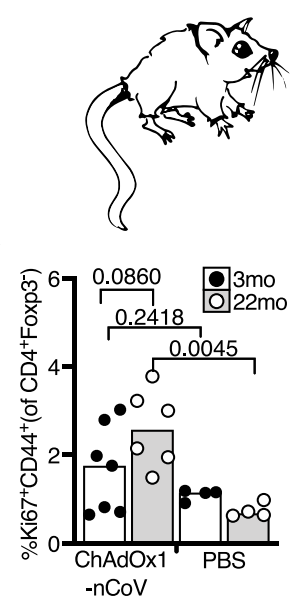

N

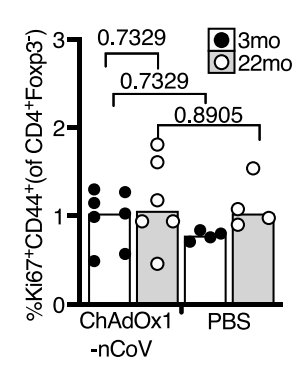

J

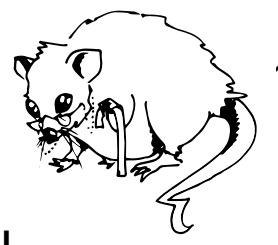

$\mathbf{L}$

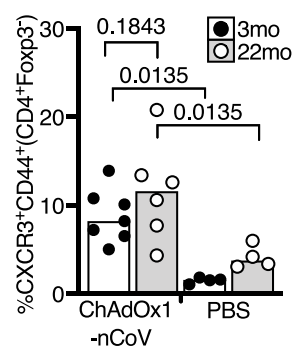

0

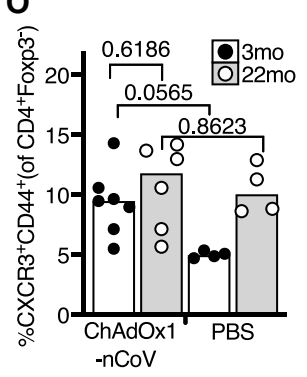

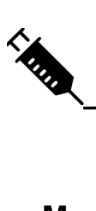

M

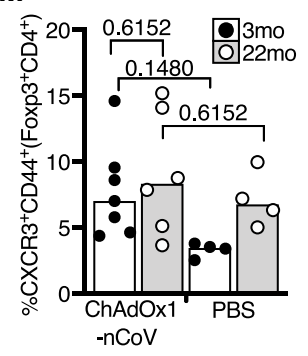

$\mathbf{P}$

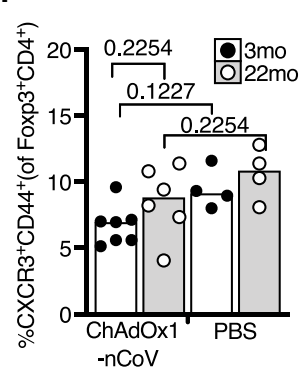

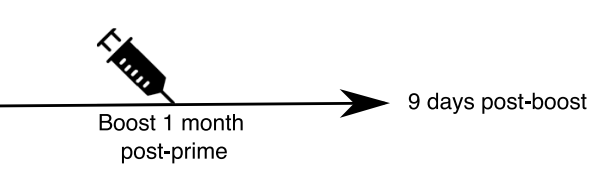

Q

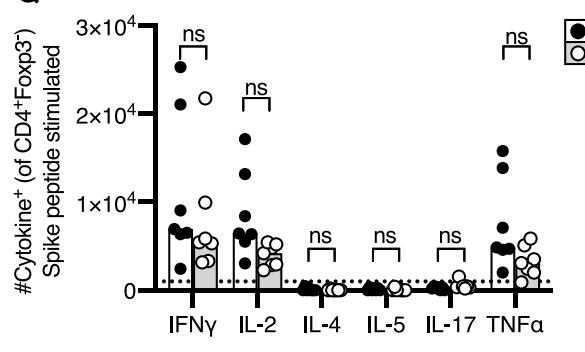

$\mathbf{R}$

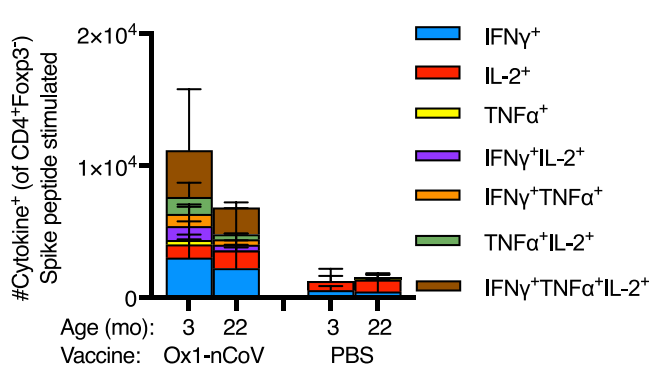




\section{CellPress}

that the $\mathrm{CD}^{+} \mathrm{T}$ cell response to $\mathrm{ChAdO} \times 1 \mathrm{nCoV}-19$ immunization is largely intact in aged mice, with a slight deficiency in antigen-specific cytokine production that can be enhanced by a booster immunization.

\section{Aged Mice Have an Impaired Germinal Center Response after Primary Immunization \\ The majority of clinically available vaccines are thought to provide protection by elic- iting humoral immunity. Therefore, it was important to quantify the B cell response to ChAdOx1 nCoV-19 vaccination in the context of aging. Early antibody production after vaccination arises from antibody-secreting cells generated in the extrafollicular plasma cell response, which is fast but typically short lived. ${ }^{33}$ A comparable early plasma cell response was detected in the iLN of younger adult and aged mice after immunization (Figures 6A and 6B), although there was an increase in the proportion of IgM $^{+}$plasma cells in aged mice (Figure $6 \mathrm{C}$ ). An intact plasma cell response was coupled with an increase in anti-spike antibodies 9 days after immunization. These were of only slightly lower titer in aged mice, and of similar lgG subclass distribution to younger animals, indicative of a predominantly Th1-dominated response (Figures 6D-6F).}

Long-lived antibody-secreting cells typically arise from the germinal center response. ${ }^{34}$ The percentage, but not total number, of germinal center B cells was reduced in aged mice compared to younger adult mice after ChAdOx 1 nCoV-19 vaccination (Figures $6 \mathrm{G}$ and $6 \mathrm{H}$ ). Like the plasma cell response, there were more $\mathrm{IgM}^{+}$germinal center B cells in aged mice (Figure 6l). An increase in T follicular helper cells, but not $T$ follicular regulatory cells, accompanied the lymph node germinal center response in adult and aged mice (Figures 6J and 6K). In the spleen, germinal centers were easily visualized by microscopy in adult mice 9 days after ChAdOx 1 $\mathrm{nCoV}-19$ vaccination but were conspicuously absent in aged mice (Figure 6L; Figure S5). Quantification of splenic germinal centers by flow cytometry confirmed impaired germinal center formation in aged mice (Figures $6 \mathrm{~N}$ and 60 ). This was accompanied by fewer proliferating non-germinal center $\mathrm{B}$ cells and $\mathrm{T}$ follicular helper cells in aged mice (Figures 6P and 6Q). As in the draining lymph node, splenic $T$ follicular regulatory cells were not induced by $\mathrm{ChAdO} \times 1 \mathrm{nCoV}-19$ vaccination at this time point (Figure 6R). The impact of an impaired germinal center response on spikespecific antibodies was observed 28 days after immunization, with aged mice having lower titers of anti-spike IgM and IgG (Figures 6S and 6T) but a similar profile of IgG

Figure 5. The CD4 Cell Response to ChAdOx1 nCoV-19 in Aged Mice

(A) Cartoon of prime immunization strategy.

(B-G) Percentage of proliferating Ki67 ${ }^{+}$(B), $\mathrm{CXCR} 3^{+} \mathrm{CD} 44^{+} \mathrm{CD} 4 \mathrm{~T}$ cells $(\mathrm{C})$ and $\mathrm{CXCR} 3^{+} \mathrm{CD} 44^{+} \mathrm{Foxp} 3^{+}$Treg cells (D) in the draining iliac lymph node. Percentage of proliferating $\mathrm{Ki}_{67}{ }^{+}(\mathrm{E}), \mathrm{CXCR} 3^{+} \mathrm{CD} 44^{+} \mathrm{CD} 4 \mathrm{~T}$ cells $(\mathrm{F})$ and $\mathrm{CXCR} 3^{+} \mathrm{CD} 44^{+} \mathrm{Foxp} 3^{+}$Treg cells $(\mathrm{G})$ in the spleen of 3-month-old or 22-monthold mice 9 days after immunization with $\mathrm{ChAdO} \times 1 \mathrm{nCoV}-19$ or PBS.

( $\mathrm{H}$ and I) Number of $\mathrm{CD}^{+}{ }^{+} \mathrm{Foxp}^{-}$cells producing IFN- $\gamma, \mathrm{IL}-2, \mathrm{IL}-4, \mathrm{IL}-5, \mathrm{IL}-17$, or TNF- $\alpha 6 \mathrm{~h}$ after restimulation with SARS-CoV-2 peptide pools in (I), and the number of single and multiple cytokine-producing $C D 4^{+} \mathrm{T}$ cells are represented in stacked bar charts.

(J) Cartoon of prime-boost immunization strategy.

(K-M) Percentage of proliferating Ki67 ${ }^{+}(\mathrm{K}), \mathrm{CXCR} 3^{+} \mathrm{CD} 44^{+} \mathrm{CD} 4 \mathrm{~T}$ cells (L), and $\mathrm{CXCR} 3^{+} \mathrm{CD} 44^{+} \mathrm{Foxp} 3^{+}$Treg cells (M) in the draining iliac lymph node. (N-P) Percentage of Ki67 ${ }^{+} \mathrm{CD}_{4} 4^{+}(\mathrm{N}), \mathrm{CXCR} 3^{+} \mathrm{CD} 44^{+} \mathrm{CD} 4^{+} \mathrm{Foxp}^{-} \mathrm{T}$ cells $(\mathrm{O})$, and $\mathrm{CXCR} 3^{+} \mathrm{CD} 44^{+} \mathrm{Foxp}^{+}$Treg cells (P) in the spleen of 3-month-old or 22-month-old mice 9 days after immunization with ChAdOx $1 \mathrm{nCoV}-19$ or PBS.

( $Q$ and R) Number of CD4 ${ }^{+}$Foxp3- $T$ cells producing IFN- $\gamma$, IL-2, IL-4, IL-5, IL-17, or TNF- $\alpha 6$ h after restimulation with SARS-CoV-2 peptide pools in (R), and the number of single and multiple cytokine-producing $C D 4^{+} T$ cells are represented in stacked bar charts. In $(B-H)$ and $(K-P)$, the bar height corresponds to the median, and each circle represents one biological replicate.

In (I) and (R), each bar segment represents the mean and the error bars the standard deviation. The Shapiro-Wilk normality test was used to determine whether the data are consistent with a normal distribution, followed by either an ordinary one-way ANOVA test for data with a normal distribution or a Kruskal-Wallis test for non-normally distributed data alongside a multiple comparisons test. Data are representative of two independent experiments ( $n=4-8$ per group/experiment). 

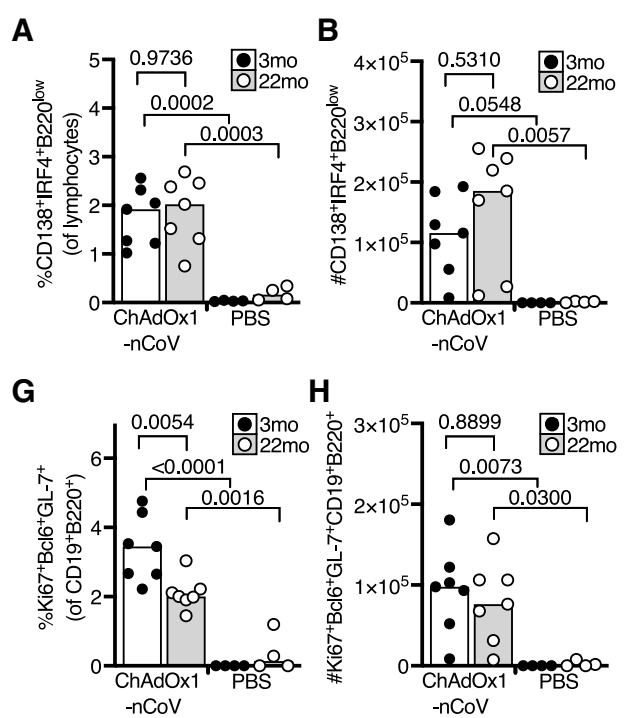

H

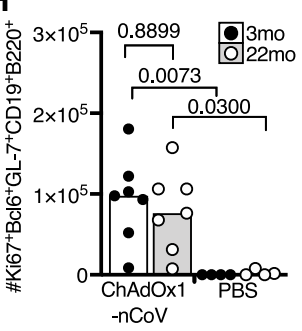

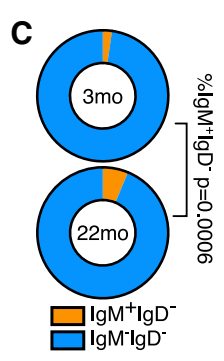
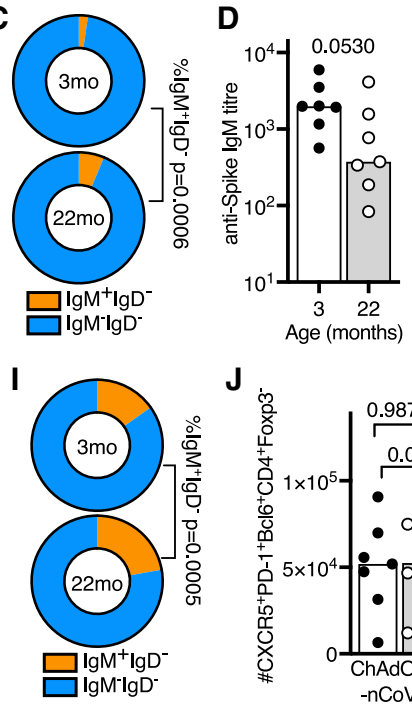
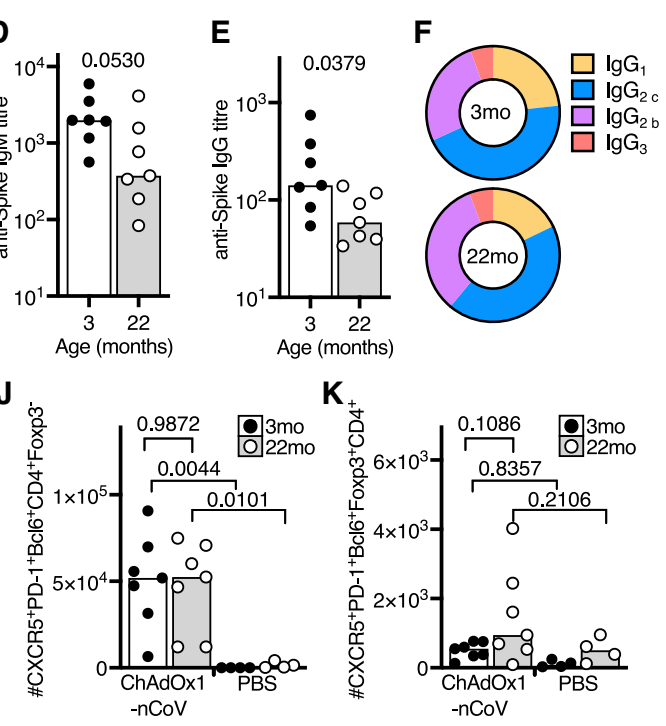

$\mathbf{L}$
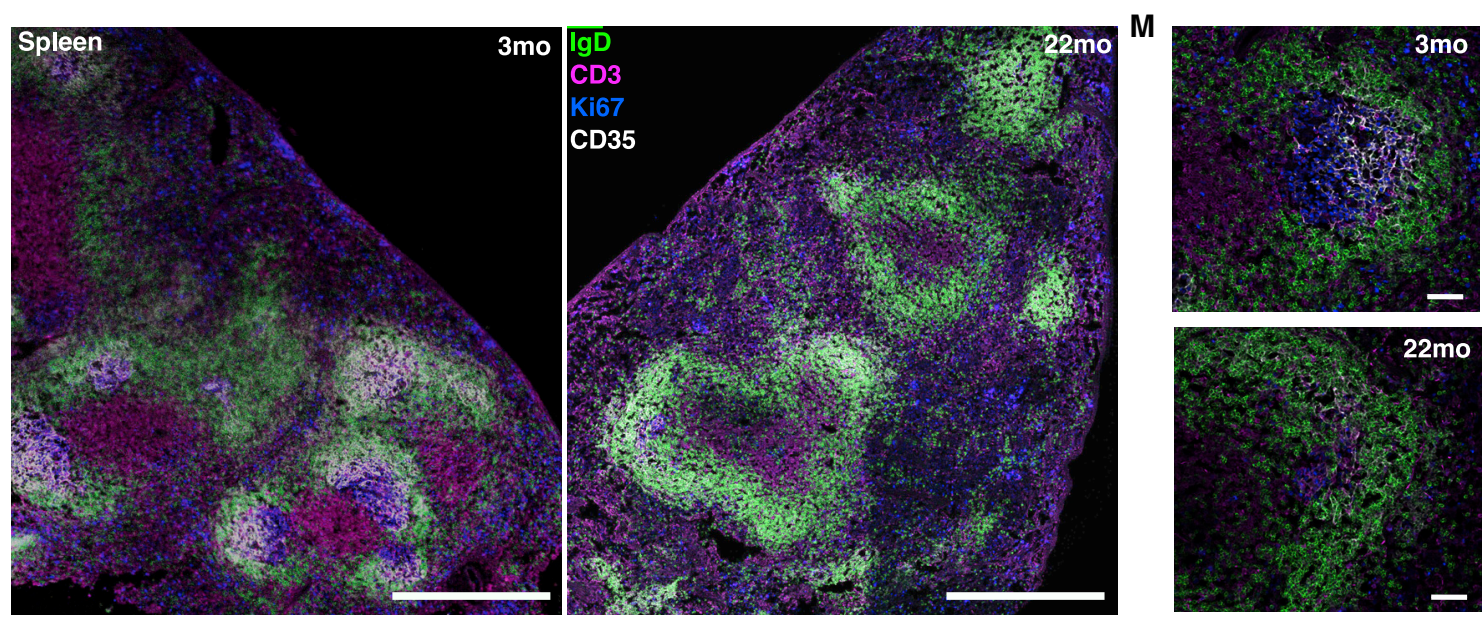

$\mathbf{N}$

O

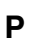

$\mathbf{P}$
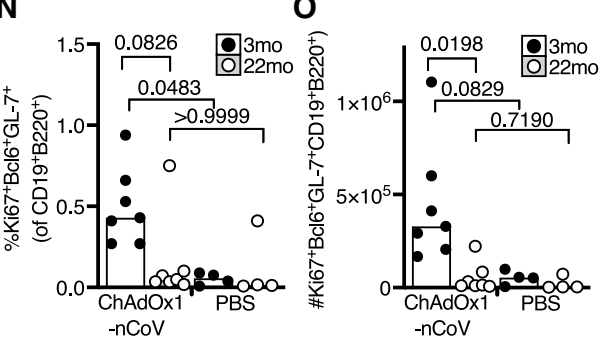

$\mathbf{S}$
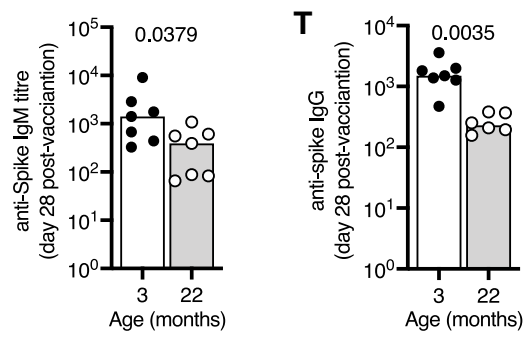

Q

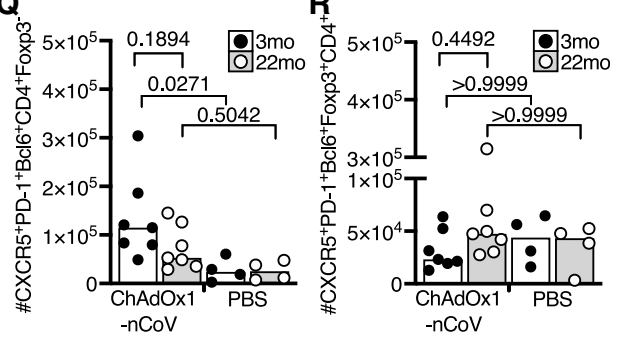

U
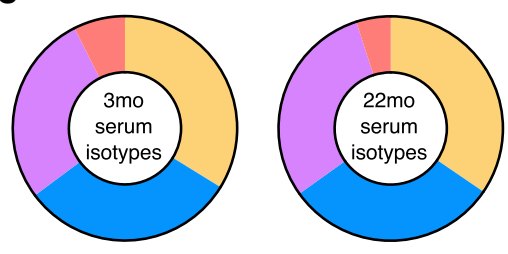

$\square \lg G_{1}$

$\lg G_{20}$

$\square \lg _{2 \mathrm{~b}}$ 


\title{
CellPress
}

\section{Clinical and Translational Article}

subclasses (Figure 6U). Together, these data indicate that, while a single of dose of ChAdOx1 nCoV-19 can induce comparable extrafollicular plasma cell responses between younger adult and aged mice, the germinal center response is compromised with age.

\begin{abstract}
A Second Dose of ChAdOx1 nCoV-19 Boosts Humoral Immunity in Aged Mice To test whether a prime-boost strategy can enhance the $B$ cell response in aged mice, a prime-boost approach was taken (Figure 7A). Nine days after boost, there were $\mathrm{Ki} 7^{+}$non-germinal center $\mathrm{B}$ cells, plasma cells and germinal center B cells in the draining lymph nodes of aged mice (Figures 7B-7H). Notably, the magnitude of the germinal center response was larger in aged mice than in younger adult mice after boost (Figures $7 \mathrm{~F}-7 \mathrm{H}$ ), and this was associated with increased $\mathrm{T}$ follicular helper and $\mathrm{T}$ follicular regulatory cell numbers (Figures $7 \mathrm{I}$ and $7 \mathrm{~J}$ ). A germinal center response was not observed in the spleen of either adult or aged mice 9 days after booster immunization (Figure 7K). This demonstrates that a second dose of ChAdOx1 nCoV-19 can enhance the $B$ cell response in aged mice. This improvement in the $B$ cell response corresponded to an increase in anti-spike lgG, without skewing IgG subclasses, antibodies in every aged mouse that was given a booster immunization (Figures $7 \mathrm{~L}-7 \mathrm{O}$ ). The post-boost ratio of $\operatorname{lgG}_{2} / \mathrm{lgG}_{1}$ was 3.7 (3.0) in younger adult and 2.6 (1.6) in aged mice (mean and standard deviation). The functional effect of the humoral immunity after both prime and boost immunizations was measured by SARS-CoV-2 pseudotyped virus microneutralization assay. Nine days after prime immunization, SARS-CoV-2 neutralizing antibodies were at a lower titer in aged mice than measured in adult mice (Figure 7P). Nine days after boost, neutralizing antibodies were detectable in all aged mice and had been boosted 8-fold compared to post-prime, although the titer was lower than in younger adult mice (Figure 7P). The SARS-CoV-2 neutralizing antibody titer positively correlated with anti-spike IgG titer in aged mice, indicating that the main limitation in age-dependent humoral immunity is quantity, rather than function (Figure 7R). This demonstrates that a booster dose of ChAdOx1 nCoV-19 can improve anti-spike humoral immunity in older mice.
\end{abstract}

\section{DISCUSSION}

The development of an effective anti-SARS-CoV-2 vaccine represents an opportunity to limit the health, social, and economic consequences of the current pandemic. Since

Figure 6. Impaired B Cell Responses after ChAdOx1 nCoV-19 Immunization of Aged Mice

( $A$ and $B$ ) B cell response in 3-month-old (3mo) or 22-month-old (22mo) mice 9 days after immunization with ChAdOx1 nCoV-19 or PBS. Flow cytometric evaluation of the percentage $(A)$ and number $(B)$ of plasma cells in the iliac lymph node.

(C) Pie charts showing the proportion of $\operatorname{lgM}^{+} \operatorname{IgD}^{-}$(orange) and switched $\operatorname{lgM}^{-} \operatorname{lgD}^{-}$(blue) plasma cells from (A) and (B).

(D and E) Serum IgM (D) and IgG (E) anti-spike antibodies 9 days after immunization.

(F) Pie charts showing the proportion of anti-spike IgG of the indicated subclasses in the serum 9 days after immunization.

$(\mathrm{G}$ and $\mathrm{H}$ ) Percentage $(\mathrm{G})$ and number $(\mathrm{H})$ of germinal center $\mathrm{B}$ cells in the iliac lymph node.

(I) Pie charts showing the proportion of $\operatorname{lgM}^{+} \mathrm{IgD}^{-}$(orange) and switched $\mathrm{IgM}^{-} \mathrm{IgD}^{-}$(blue) germinal center cells from (G) and (H).

$(\mathrm{J}-\mathrm{M})$ Number of $\mathrm{T}$ follicular helper $(\mathrm{J})$ and $\mathrm{T}$ follicular regulatory $(\mathrm{K})$ cells in the draining lymph node. Confocal images of the spleen of ChAdOx1 $\mathrm{nCoV}$ 19-immunized mice of the indicated ages; in (L), the scale bars represent $500 \mu \mathrm{m}$; in (M), the scale bars represent $50 \mu \mathrm{m}$. IgD $\mathrm{B}^{+} \mathrm{B}$ cell follicle are in green, $\mathrm{CD}^{+} \mathrm{T}$ cells in magenta, $\mathrm{Ki} 67^{+}$cells in blue, and $\mathrm{CD} 35^{+}$follicular dendritic cells in white.

$(\mathrm{N}$ and $\mathrm{O})$ Percentage $(\mathrm{N})$ and number $(\mathrm{O})$ of splenic germinal center $\mathrm{B}$ cells.

(P) Percentage of $\mathrm{Ki}^{+} 7^{+} \mathrm{B}$ cells in the spleen.

( $Q$ and $R$ ) Number of splenic $T$ follicular helper (Q) and T follicular regulatory (R) cells.

Serum IgM (S) and IgG (T) anti-spike antibodies and IgG subclasses (U) 28 days after immunization. For all bar graphs, the bar height corresponds to the median and each circle represents one biological replicate. The Shapiro-Wilk normality test was used to determine whether the data are consistent with a normal distribution, followed by either an ordinary one-way ANOVA test for data with a normal distribution or a Kruskal-Wallis test for non-normally distributed data alongside a multiple comparisons test, for ELISA data analyses were done on log transformed values. Data are representative of two independent experiments ( $n=4-8$ per group/experiment). 
A

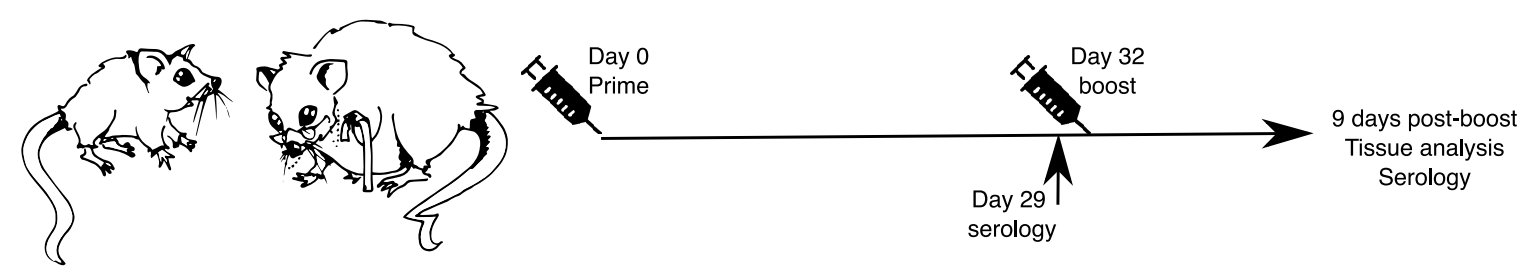

B

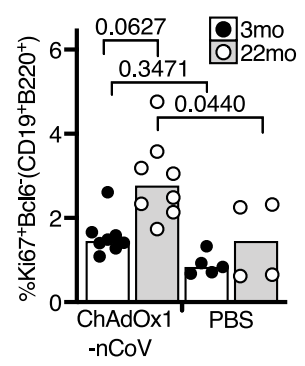

G

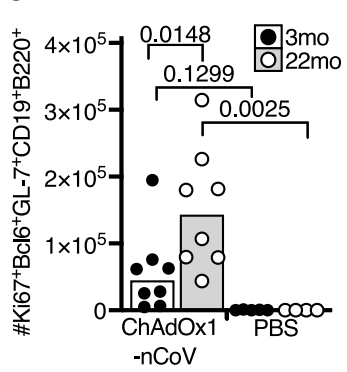

$\mathbf{L}$

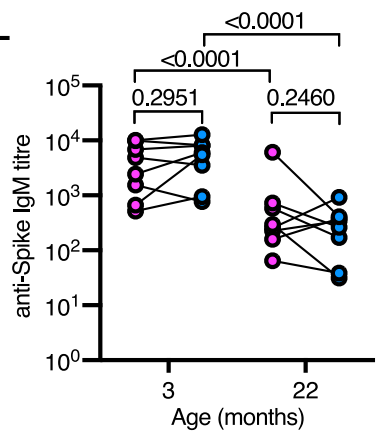

$\mathbf{P}$

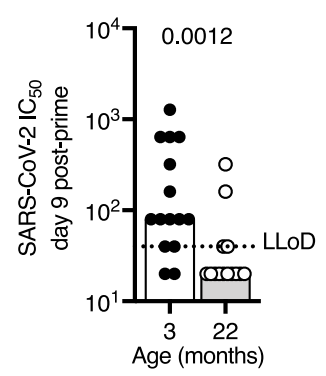

C

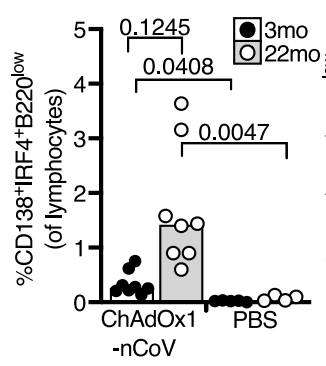

D

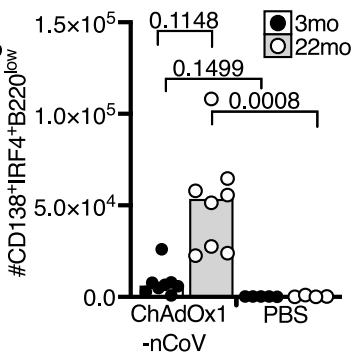

E

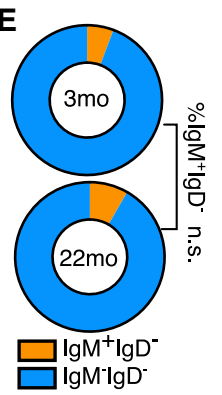

$\mathbf{F}$

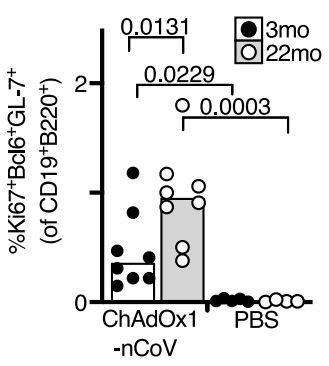

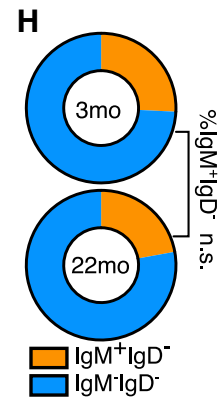

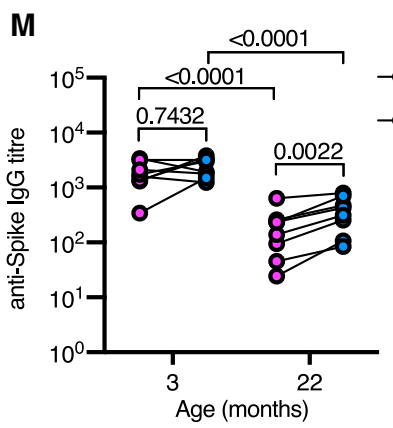

$\mathbf{N}$

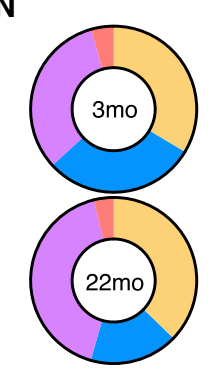

day 29 post prime
K

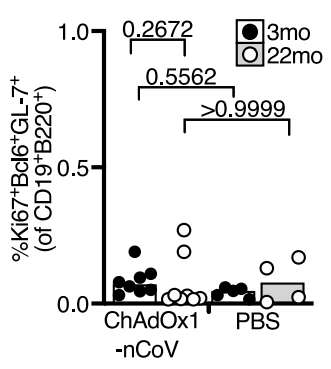

0

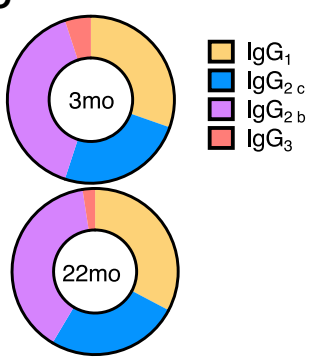

day 9 post boost
Q

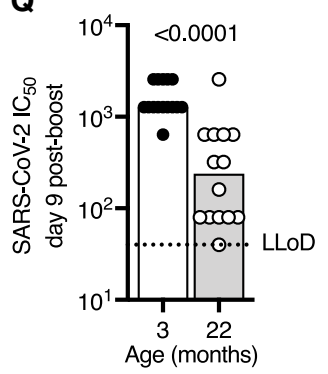

$\mathbf{R}$

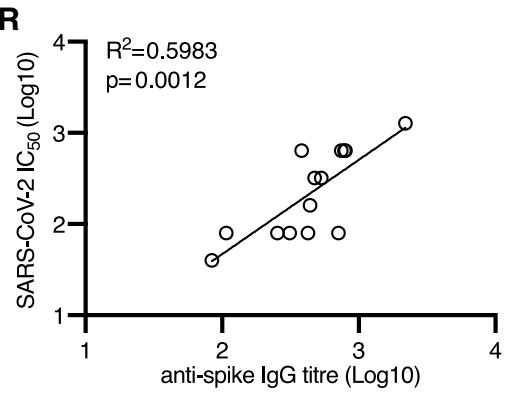

Figure 7. A Booster Immunization Enhances the B Cell Response to ChAdOx1 nCoV-19 Immunization in Aged Mice (A) Scheme of the prime-boost immunization protocol.

(B) Percentage of $\mathrm{Ki} 7^{+} \mathrm{B}$ cells in the draining lymph node.

(C and D) Percentage (C) and number (D) plasma cells in the iliac lymph node. 


\section{CellPress}

older adults are more likely to have severe health outcomes after infection, a vaccination strategy that provides protection for this group is particularly desirable. Here, we provide the most detailed immunophenotyping analysis to date of how the murine immune system following ChAdOx1 $\mathrm{nCoV}-19$ vaccination. This vaccine stimulates both cellular and humoral immunity. Vaccination of younger adult mice triggers formation of spikespecific polyfunctional $\mathrm{CD}^{+}$and Th1 cells that persist for at least 21 days after immunization. The first surge of antibodies come from short-lived plasma cells, that produce low levels of neutralizing antibodies. Germinal centers and T follicular helper cells are established later in the response, which contribute to longer term antibody titers. One dose of this vaccine stimulates an immune response in aged mice, but it is of reduced magnitude compared to that seen in younger adult animals. Importantly, the data presented here show that a second homologous immunization was able to enhance the $\mathrm{B}$ cell, helper $\mathrm{T}$ cell, and $\mathrm{CD}^{+} \mathrm{T}$ cell response in aged mice. In people, the same prime-boost approach had an acceptable safety profile and enhanced humoral immunity, ${ }^{28}$ indicating that this is a rational vaccination approach for use in the older members of our communities-arguably the sector of society most in need of an effective vaccine to prevent COVID-19.

Strategies that are able to enhance humoral immunity in older individuals are key to vaccine efficacy, particularly as in some respiratory infections, a higher titer of antibodies are required to be protective. ${ }^{35,36}$ Antibody-secreting cells can form from two cellular pathways, but these are not equal in terms of quality or longevity. The extrafollicular response produces an initial burst of antibodies early after antigenic challenge. This response is short lived with no additional diversification of the $B$ cell repertoire, and thus its contribution to long-term immunity is minimal. ${ }^{33}$ The germinal center reaction is a specialized microenvironment that produces memory $B$ cells and long-lived antibody secreting plasma cells with somatically mutated immunoglobulin (lg) genes. ${ }^{34,37,38}$ The germinal center is the only cellular source of long-lived plasma cells ${ }^{39}$ and the only known site where the $\mathrm{B}$ cell response can be altered in response to antigen. Nine days after ChAdOx1 nCoV-19 immunization, the formation of plasma cells was comparable in young and aged mice, a time at which the majority of plasma cells derive from the extrafollicular response. ${ }^{39}$ By contrast, the germinal center response was diminished in aged mice, which is a well-described deficit of the older immune system after vaccination. ${ }^{17,40}$ This indicates that poor germinal center formation is the major barrier that must be overcome to improve humoral immunity in older individuals. A booster dose of ChAdOx1 $\mathrm{nCoV}-19$ enhanced the magnitude of the germinal center response in aged mice, to a greater extent than it did in younger animals. This may be because younger mice have produced higher titers of anti-vaccine vector antibodies, which limits the action of a second dose.

(E) Pie charts showing the proportion of $\operatorname{lgM}^{+} \lg D^{-}$(orange) and switched $\operatorname{lgM}^{-} \lg D^{-}$(blue) plasma cells from (B) and (C).

( $F$ and $G$ ) Percentage (F) and number (G) of germinal center B cells in the iliac lymph node.

$(\mathrm{H})$ Pie charts showing the proportion of $\operatorname{lgM}^{+} \operatorname{lgD}^{-}$(orange) and switched $\operatorname{lgM}^{-} \lg \mathrm{D}^{-}$(blue) germinal center cells from (F) and (G).

(I and J) Number of T follicular helper (I) and T follicular regulatory (J) cells in the draining lymph node.

(K) Percentage (K) of splenic germinal center B cells.

$(L-O)$ Serum anti-spike IgM (L), IgG (M), and IgG subclasses ( $N$ and $O$ ) prior to boost (day 29) and 9 days after boost immunization.

(P and Q) SARS-CoV-2 neutralizing antibody titers in sera were determined by micro neutralization test, expressed as reciprocal serum dilution to inhibit pseudotyped virus entry by $50 \%\left(I C_{50}\right)$. Samples below the lower limit of detection (LLoD) are shown as half of the LLoD.

(R) Linear regression of serum dilution to inhibit pseudotyped virus entry by 50\% (IC 50 Log10) and serum anti-spike ELISA titer (Log10) in 22-month-old mice, 9 days post-boost. For all bar graphs, the bar height corresponds to the median and each circle represents one biological replicate. The ShapiroWilk normality test was used to determine whether the data are consistent with a normal distribution, followed by either an ordinary one-way ANOVA test for data with a normal distribution or a Kruskal-Wallis test for non-normally distributed data alongside a multiple comparisons test. For ELISA, data analyses were done on log transformed values. $\ln (B)-(O)$, data are shown from one of two independent experiments $(n=4-8$ per group/experiment); in $(\mathrm{P})-(\mathrm{R})$, the data are pooled from two experiments 
Another feature of the aged germinal center reaction is reduced selection of highaffinity $B$ cells, resulting in a diminished quality of the response in aging. ${ }^{19}$ Whether the further diversification and affinity-based selection of the $B$ cell receptor is important for protective humoral immunity to SARS-CoV-2 has yet to be established. However, antibodies isolated from spike-specific B cells from convalescent COVID-19 patients can be both potently neutralizing and have low levels of somatic hypermutation, ${ }^{41-43}$ indicating that extensive somatic hypermutation is not required for antiSARS-CoV-2-neutralizing antibody formation. Therefore, the main barrier to inducing protective humoral immunity to SARS-CoV-2 in older people may be an issue of enhancing the magnitude, rather than quality, of the germinal center response. Our study shows this can be achieved in aged mice by giving a second dose of the vaccine.

A rapid recall of memory $\mathrm{CD}^{+} \mathrm{T}$ cells in response to viral infections complements the humoral response by promoting efficient pathogen clearance and this becomes particularly important in scenarios where the protective ability or magnitude of neutralizing antibodies is compromised. ${ }^{44}$ A single dose of ChAdOx1 $\mathrm{nCoV}-19$ vaccine induces a $\mathrm{CD}^{+} \mathrm{T}$ cell response in both adult and aged mice. There was, however, a profound defect in the generation of spike-reactive CD ${ }^{+}$ $T$ cells that produced granzyme B, a key cytotoxic effector molecule produced by effector $\mathrm{CD}^{+} \mathrm{T}$ cells. This failure to generate granzyme $\mathrm{B}^{+} \mathrm{CD} 8^{+} \mathrm{T}$ cells is a common feature in aging, previously observed in aged mice after West Nile Virus infection $^{45}$ and in aged monkeys infected with SARS-CoV. ${ }^{46}$ A similar trend for fewer granzyme $\mathrm{B}^{+} \mathrm{CD}^{+}$cells in older people was observed after influenza vaccination. ${ }^{47}$ Consistent with reduced expression of granzyme B in T cells from older adults, $T$ cells taken from older adults have an impaired ability to kill influenza infected cells ex vivo. ${ }^{48}$ In a small study of older people, induction of granzyme B after influenza vaccination was a correlate of protection in older adults. ${ }^{36}$ Here, we demonstrate that a second dose of ChAdOx1 nCoV-19 was able to correct the defective granzyme $\mathrm{B}^{+} \mathrm{CD}^{+} \mathrm{T}$ cell response in aged mice, indicating that two doses of this vaccine is a better approach to enhance the cellular immune response in older bodies.

ChAdOx1 nCoV-19 is currently being trialed in older adults as part of a phase III trial, which will ultimately determine whether it is an effective vaccine for this demographic. Immunization of people over 55 years of age with adenovirus type5(Ad5)-vectored COVID-19 vaccine resulted in lower antibody titers in the older age group, suggesting that adenoviral vectored vaccine strategies may require more than one dose in older people. ${ }^{49}$ However, as pre-existing immunity to Ad5, a naturally occurring human tropic adenovirus, can inhibit the response to this vaccine, it is possible that the reduced immunogenicity of this vaccine is due to an increased prevalence of antibodies to the vaccine vector in this age group. By contrast, the presence of anti-ChAdOx1 antibodies in the general population is low. ${ }^{50}$ The work presented here demonstrates that one dose of this vaccine is immunogenic in aged mice, but this response can be significantly improved with a second booster dose. Given that a second dose of ChAdOx1 $\mathrm{nCoV}-19$ is immunogenic with expected reactogenicity profile in humans, ${ }^{28}$ this may be a viable strategy to enhance immunogenicity and possibly efficacy in older people.

\section{Limitations of Study}

This study used aged mice as a pre-clinical model to test the immunogenicity of ChA$\mathrm{dO} \times 1 \mathrm{nCoV}-19$ in older bodies. One limitation of this study was that SARS-CoV-2 


\section{CellPress}

OPEN ACCESS

infections were not performed to test the protection conferred by vaccination. SARSCoV-2 does not naturally infect mice; to circumvent this limitation, mouse adapted strains have been generated. ${ }^{51,52}$ In order to bind to the mouse angiotensin-converting enzyme 2, SARS-CoV-2 requires amino acid substitutions in the receptor binding domain of the spike protein. As such, challenge with mouse adapted SARS-CoV-2 frequently mismatches vaccine encoded antigens and may not reflect real-world scenarios. The data presented in this manuscript show that a second dose of ChAdOx1 $\mathrm{nCoV}-19$ increases anti-spike lgG titer and SARS-CoV-2 pseudovirus neutralizing antibody titer in aged mice, both of which are correlates of protection against SARS-CoV2 infection in species that are susceptible to the wild-type virus. ${ }^{53,54}$

\section{STAR $\star$ METHODS}

Detailed methods are provided in the online version of this paper and include the following:

- KEY RESOURCES TABLE

- RESOURCE AVAILABILITY

○ Lead Contact

O Materials Availability

O Data and Code Availability

- EXPERIMENTAL MODEL AND SUBJECT DETAIL

$\bigcirc$ Mouse housing and husbandry

- METHODS DETAILS

O Immunisation and tissue sampling

○ Flow cytometry

O Confocal imaging

- Enzyme-linked immunosorbent assay (ELISA)

O Micro neutralisation test using lentiviral-based pseudotypes bearing the SARS-CoV-2 Spike

- QUANTIFICATION AND STATISTICAL ANALYSIS

\section{SUPPLEMENTAL INFORMATION}

Supplemental Information can be found online at https://doi.org/10.1016/j.medj. 2020.12.006.

\section{ACKNOWLEDGMENTS}

We are grateful to Dr. Martin Turner, Dr. Geoff Butcher, Marc Wiltshire, Paul Symonds, and Prof. Michael Wakelam for their support. We thank Dr. Hayley Sharpe and Dr. Heidi Welch for technical assistance. This study was supported by funding from the Biotechnology and Biological Sciences Research Council (BBS/E/B/ 000C0427, BBS/E/B/000C0428, and the Campus Capability Core Grant to the Babraham Institute), the Lister institute of Preventative Medicine, the EPSRC VaxHub (EP/RO13756/1), and Innovate UK (biEBOV: 971615). T.L. and S.C.G. are Jenner Investigators. M.A.L. is an EMBO Young Investigator and a Lister Institute Prize Fellow. J.L.L. is supported by a National Science Scholarship (PhD) by the Agency for Science, Technology and Research, Singapore.

\section{AUTHOR CONTRIBUTIONS}

Conceptualization, M.A.L. and T.L.; Methodology, A.S.-C., W.S.F., S.I., O.T.B., A.J.S., S.B.-R., D.W., J.B., D.B., S.F.-B., M.A.L., N.T., C.C., N.E.-B., and C.N.; Investigation, A.S.-C., W.S.F., S.I., O.T.B., S.F.-B., A.J.S., N.T., C.C., S.B.-R., J.L.L., and M.A.L; Writing - Original Draft Preparation, M.A.L., A.S.-C., W.S.F., J.L.L., and T.L.; Writing - Review and Editing, all authors; Project Administration, S.I., M.A.L., and T.L.; Funding Acquisition, M.A.L., S.C.G., and T.L. 
Med

Clinical and Translational Article

\section{DECLARATION OF INTERESTS}

S.C.G. and T.L. are named on a patent application covering ChAdOx1 nCoV-19. The remaining authors declare no competing interests. The funders played no role in the conceptualization, design, data collection, analysis, decision to publish, or preparation of the manuscript.

Received: November 4, 2020

Revised: November 20, 2020

Accepted: December 2, 2020

Published: December 16, 2020

\section{REFERENCES}

1. Zhu, N., Zhang, D., Wang, W., Li, X., Yang, B. Song, J., Zhao, X., Huang, B., Shi, W., Lu, R., et al.; China Novel Coronavirus Investigating and Research Team (2020). A Novel

Coronavirus from Patients with Pneumonia in China, 2019. N. Engl. J. Med. 382, 727-733.

2. Wu, F., Zhao, S., Yu, B., Chen, Y.M., Wang, W., Song, Z.G., Hu, Y., Tao, Z.W., Tian, J.H., Pei, Y.Y., et al. (2020). A new coronavirus associated with human respiratory disease in China. Nature 579, 265-269.

3. Hoffmann, M., Kleine-Weber, H., Schroeder, S., Kruger, N., Herrler, T., Erichsen, S., Schiergens, T.S., Herrler, G., Wu, N.H., Nitsche, A., et al. (2020). SARS-CoV-2 Cell Entry Depends on ACE2 and TMPRSS2 and Is Blocked by a Clinically Proven Protease Inhibitor. Cell 181, 271-280.

4. Wu, Z., and McGoogan, J.M. (2020). Characteristics of and Important Lessons From the Coronavirus Disease 2019 (COVID-19) Outbreak in China: Summary of a Report of 72314 Cases From the Chinese Center for Disease Control and Prevention. JAMA 323, 1239-1242

5. Wu, C., Chen, X., Cai, Y., Xia, J., Zhou, X., Xu, S., Huang, H., Zhang, L., Zhou, X., Du, C., et al. (2020). Risk Factors Associated with Acute Respiratory Distress Syndrome and Death in Patients With Coronavirus Disease 2019 Pneumonia in Wuhan, China. JAMA Intern Med 180, 934-943.

6. Grasselli, G., Zangrillo, A., Zanella, A., Antonelli, M., Cabrini, L., Castelli, A., Cereda, D., Coluccello, A., Foti, G., Fumagalli, R., et al. (2020). Baseline Characteristics and Outcomes of 1591 Patients Infected With SARS-CoV-2 Admitted to ICUs of the Lombardy Region. JAMA 323, 1574-1581.

7. Lurie, N., Saville, M., Hatchett, R., and Halton, J. (2020). Developing Covid-19 Vaccines at Pandemic Speed. N. Engl. J. Med. 382, 19691973.

8. Sharpe, H.R., Gilbride, C., Allen, E., BelijRammerstorfer, S., Bissett, C., Ewer, K., and Lambe, T. (2020). The early landscape of coronavirus disease 2019 vaccine development in the UK and rest of the world. Immunology 160, 223-232

9. Govaert, T.M., Thijs, C.T., Masurel, N., Sprenger, M.J., Dinant, G.J., and Knottnerus, J.A. (1994). The efficacy of influenza vaccination in elderly individuals. A randomized double- blind placebo-controlled trial. JAMA 272 1661-1665

10. Ortqvist, A., Hedlund, J., Burman, L.A., Elbel, E., Höfer, M., Leinonen, M., Lindblad, I., Sundelöf, B., and Kalin, M.; Swedish Pneumococcal Vaccination Study Group (1998). Randomised trial of 23-valent pneumococcal capsular polysaccharide vaccine in prevention of pneumonia in middleaged and elderly people. Lancet 351, 399-403.

11. Stiasny, K., Aberle, J.H., Keller, M., GrubeckLoebenstein, B., and Heinz, F.X. (2012). Age affects quantity but not quality of antibody responses after vaccination with an inactivated flavivirus vaccine against tick-borne encephalitis. PLoS ONE 7, e34145.

12. Burns, E.A., Lum, L.G., L'Hommedieu, G., and Goodwin, J.S. (1993). Specific humoral immunity in the elderly: in vivo and in vitro response to vaccination. J. Gerontol. 48, B231B236.

13. Vanhooren, V., and Libert, C. (2013). The mouse as a model organism in aging research: usefulness, pitfalls and possibilities. Ageing Res. Rev. 12, 8-21.

14. Goronzy, J.J., and Weyand, C.M. (2019) Mechanisms underlying $T$ cell ageing. Nat. Rev. Immunol. 19, 573-583.

15. Frasca, D., Blomberg, B.B., Garcia, D., Keilich, S.R., and Haynes, L. (2020). Age-related factors that affect $B$ cell responses to vaccination in mice and humans. Immunol. Rev. 296, 142-154.

16. Gustafson, C.E., Kim, C., Weyand, C.M., and Goronzy, J.J. (2020). Influence of immune aging on vaccine responses. J. Allergy Clin. Immunol. 145, 1309-1321.

17. Stebegg, M., Bignon, A., Hill, D.L., SilvaCayetano, A., Krueger, C., Vanderleyden, I. Innocentin, S., Boon, L., Wang, J., Zand, M.S et al. (2020). Rejuvenating conventional dendritic cells and T follicular helper cell formation after vaccination. eLife 9, e52473.

18. Nakaya, H.I., Hagan, T., Duraisingham, S.S. Lee, E.K., Kwissa, M., Rouphael, N., Frasca, D., Gersten, M., Mehta, A.K., Gaujoux, R., et al. (2015). Systems Analysis of Immunity to Influenza Vaccination across Multiple Years and in Diverse Populations Reveals Shared Molecular Signatures. Immunity 43, 1186-1198.

19. Yang, X., Stedra, J., and Cerny, J. (1996). Relative contribution of $T$ and $B$ cells to hypermutation and selection of the antibody
CellPress OPEN ACCESS repertoire in germinal centers of aged mice. J. Exp. Med. 183, 959-970.

20. Lefebvre, J.S., Maue, A.C., Eaton, S.M., Lanthier, P.A., Tighe, M., and Haynes, L. (2012). The aged microenvironment contributes to the age-related functional defects of CD4 T cells in mice. Aging Cell 11, 732-740.

21. Praditsuwan, R., Assantachai, P., Wasi, C., Puthavatana, P., and Kositanont, U. (2005). The efficacy and effectiveness of influenza vaccination among Thai elderly persons living in the community. J. Med. Assoc. Thai. 88, 256-264.

22. Baldwin, S.L., Hsu, F.C., Van Hoeven, N., Gage, E., Granger, B., Guderian, J.A., Larsen, S.E., Lorenzo, E.C., Haynes, L., Reed, S.G., and Coler, R.N. (2018). Improved Immune Responses in Young and Aged Mice with Adjuvanted Vaccines against H1N1 Influenza Infection. Front. Immunol. 9, 295.

23. Demicheli, V., Jefferson, T., Ferroni, E., Rivetti, A., and Di Pietrantonj, C. (2018). Vaccines for preventing influenza in healthy adults. Cochrane Database Syst. Rev. 2, CD001269.

24. Hung, I.F., Zhang, A.J., To, K.K., Chan, J.F., Li, C., Zhu, H.S., Li, P., Li, C., Chan, T.C., Cheng, V.C., et al. (2014). Immunogenicity of intradermal trivalent influenza vaccine with topical imiquimod: a double blind randomized controlled trial. Clin. Infect. Dis. 59, 1246-1255.

25. Hill, D.L., Pierson, W., Bolland, D.J., Mkindi, C., Carr, E.J., Wang, J., Houard, S., Wingett, S.W., Audran, R., Wallin, E.F., et al. (2019). The adjuvant GLA-SE promotes human Tfh cell expansion and emergence of public TCR $\beta$ clonotypes. J. Exp. Med. 216, 1857-1873.

26. van Doremalen, N., Lambe, T., Spencer, A., Belij-Rammerstorfer, S., Purushotham, J.N. Port, J.R., Avanzato, V.A., Bushmaker, T., Flaxman, A., Ulaszewska, M., et al. (2020). ChAdOx1 nCoV-19 vaccine prevents SARSCoV-2 pneumonia in rhesus macaques. Nature 586, 578-582

27. Graham, S.P., McLean, R.K., Spencer, A.J., Belij-Rammerstorfer, S., Wright, D., Ulaszewska, M., Edwards, J.C., Hayes, J.W.P., Martini, V., Thakur, N., et al. (2020). Evaluation of the immunogenicity of prime-boost vaccination with the replication-deficient viral vectored COVID-19 vaccine candidate ChAdOx1 nCoV-19. NPJ Vaccines 5, 69 


\section{CellPress} OPEN ACCESS

\section{Clinical and Translational Article}

28. Folegatti, P.M., Ewer, K.J., Aley, P.K., Angus, B., Becker, S., Belij-Rammerstorfer, S., Bellamy, D., Bibi, S., Bittaye, M., Clutterbuck, E.A., et al. (2020). Safety and immunogenicity of the ChAdOx1 nCoV-19 vaccine against SARS-CoV2: a preliminary report of a phase $1 / 2$, singleblind, randomised controlled trial. Lancet 396, $467-478$.

29. Manolova, V., Flace, A., Bauer, M., Schwarz, K. Saudan, P., and Bachmann, M.F. (2008). Nanoparticles target distinct dendritic cell populations according to their size. Eur. J. Immunol. 38, 1404-1413.

30. Guilliams, M., Dutertre, C.A., Scott, C.L., McGovern, N., Sichien, D., Chakarov, S., Van Gassen, S., Chen, J., Poidinger, M., De Prijck, S., et al. (2016). Unsupervised HighDimensional Analysis Aligns Dendritic Cells across Tissues and Species. Immunity 45 , 669-684.

31. den Haan, J.M., Lehar, S.M., and Bevan, M.J. (2000). CD8(+) but not CD8(-) dendritic cells cross-prime cytotoxic T cells in vivo. J. Exp. Med. 192, 1685-1696

32. Mildner, A., and Jung, S. (2014). Development and function of dendritic cell subsets. Immunity 40, 642-656.

33. MacLennan, I.C., Toellner, K.M., Cunningham, A.F., Serre, K., Sze, D.M. Zúñiga, E., Cook, M.C., and Vinuesa, C.G. (2003). Extrafollicular antibody responses. Immunol. Rev. 194, 8-18.

34. Vinuesa, C.G., Linterman, M.A., Yu, D., and MacLennan, I.C. (2016). Follicular Helper T Cells. Annu. Rev. Immunol. 34, 335-368.

35. Dunning, A.J., DiazGranados, C.A., Voloshen, T., Hu, B., Landolfi, V.A., and Talbot, H.K. (2016). Correlates of Protection against Influenza in the Elderly: Results from an Influenza Vaccine Efficacy Trial. Clin. Vaccine Immunol. 23, 228-235.

36. McElhaney, J.E., Gravenstein, S., Upshaw, C.M., Hooton, J.W., Krause, P., Drinka, P., and Bleackley, R.C. (2001). Granzyme B: a marker of risk for influenza in institutionalized older adults. Vaccine 19, 3744-3751.

37. Shlomchik, M.J., Luo, W., and Weisel, F. (2019). Linking signaling and selection in the germinal center. Immunol. Rev. 288, 49-63.

38. Mesin, L., Ersching, J., and Victora, G.D. (2016). Germinal Center B Cell Dynamics. Immunity 45, 471-482.

39. Weisel, F.J., Zuccarino-Catania, G.V., Chikina, M., and Shlomchik, M.J. (2016). A Temporal
Switch in the Germinal Center Determines Differential Output of Memory B and Plasma Cells. Immunity 44, 116-130.

40. Zheng, B., Han, S., Takahashi, Y., and Kelsoe, G. (1997). Immunosenescence and germinal center reaction. Immunol. Rev. 160, 63-77.

41. Brouwer, P.J.M., Caniels, T.G., van der Straten, K., Snitselaar, J.L., Aldon, Y., Bangaru, S., Torres, J.L., Okba, N.M.A., Claireaux, M., Kerster, G., et al. (2020). Potent neutralizing antibodies from COVID-19 patients define multiple targets of vulnerability. Science 369 643-650.

42. Kreer, C., Zehner, M., Weber, T., Ercanoglu, M.S., Gieselmann, L., Rohde, C., Halwe, S. Korenkov, M., Schommers, P., Vanshylla, K., et al. (2020). Longitudinal Isolation of Potent Near-Germline SARS-CoV-2-Neutralizing Antibodies from COVID-19 Patients. Cell 182, 843-854.

43. Seydoux, E., Homad, L.J., MacCamy, A.J. Parks, K.R., Hurlburt, N.K., Jennewein, M.F., Akins, N.R., Stuart, A.B., Wan, Y.H., Feng, J., et al. (2020). Analysis of a SARS-CoV-2-Infected Individual Reveals Development of Potent Neutralizing Antibodies with Limited Somatic Mutation. Immunity 53, 98-105.

44. Bassi, M.R., Kongsgaard, M., Steffensen, M.A Fenger, C., Rasmussen, M., Skjødt, K., Finsen, B., Stryhn, A., Buus, S., Christensen, J.P., and Thomsen, A.R. (2015). CD8+ T cells complement antibodies in protecting against yellow fever virus. J. Immunol. 194, 1141-1153.

45. Brien, J.D., Uhrlaub, J.L., Hirsch, A., Wiley, C.A., and Nikolich-Zugich, J. (2009). Key role of T cell defects in age-related vulnerability to West Nile virus. J. Exp. Med. 206, 2735-2745.

46. Clay, C.C., Donart, N., Fomukong, N., Knight, J.B., Overheim, K., Tipper, J., Van Westrienen, J., Hahn, F., and Harrod, K.S. (2014). Severe acute respiratory syndrome-coronavirus infection in aged nonhuman primates is associated with modulated pulmonary and systemic immune responses. Immun. Ageing 11,4 .

47. McElhaney, J.E., Xie, D., Hager, W.D., Barry, M.B., Wang, Y., Kleppinger, A., Ewen, C., Kane, K.P., and Bleackley, R.C. (2006). T cell responses are better correlates of vaccine protection in the elderly. J. Immunol. 176 6333-6339.

48. Powers, D.C., and Belshe, R.B. (1993). Effect of age on cytotoxic T lymphocyte memory as well as serum and local antibody responses elicited by inactivated influenza virus vaccine. J. Infect. Dis. $167,584-592$

49. Zhu, F.C., Guan, X.H., Li, Y.H., Huang, J.Y., Jiang, T., Hou, L.H., Li, J.X., Yang, B.F., Wang, L., Wang, W.J., et al. (2020). Immunogenicity and safety of a recombinant adenovirus type-5vectored COVID-19 vaccine in healthy adults aged 18 years or older: a randomised, doubleblind, placebo-controlled, phase 2 trial. Lancet 396, 479-488.

50. Dicks, M.D., Spencer, A.J., Edwards, N.J., Wadell, G., Bojang, K., Gilbert, S.C., Hill, A.V. and Cottingham, M.G. (2012). A novel chimpanzee adenovirus vector with low human seroprevalence: improved systems for vector derivation and comparative immunogenicity. PLoS ONE 7, e40385.

51. Gu, H., Chen, Q., Yang, G., He, L., Fan, H., Deng, Y.Q., Wang, Y., Teng, Y., Zhao, Z., Cui, Y., et al. (2020). Adaptation of SARS-CoV-2 in $B A L B / c$ mice for testing vaccine efficacy. Science 369, 1603-1607

52. Dinnon, K.H., 3rd, Leist, S.R., Schäfer, A., Edwards, C.E., Martinez, D.R., Montgomery, S.A., West, A., Yount, B.L., Jr., Hou, Y.J. Adams, L.E., et al. (2020). A mouse-adapted model of SARS-CoV-2 to test COVID-19 countermeasures. Nature 586, 560-566.

53. Tostanoski, L.H., Wegmann, F., Martinot, A.J. Loos, C., McMahan, K., Mercado, N.B., Yu, J., Chan, C.N., Bondoc, S., Starke, C.E., et al. (2020). Ad26 vaccine protects against SARSCoV-2 severe clinical disease in hamsters. Nat. Med. 26, 1694-1700.

54. Yu, J., Tostanoski, L.H., Peter, L., Mercado, N.B., McMahan, K., Mahrokhian, S.H., Nkolola, J.P., Liu, J., Li, Z., Chandrashekar, A., et al. (2020). DNA vaccine protection against SARSCoV-2 in rhesus macaques. Science 369, 806-811.

55. Mähler Convenor, M., Berard, M., Feinstein, R. Gallagher, A., Illgen-Wilcke, B., PritchettCorning, K., and Raspa, M.; FELASA working group on revision of guidelines for health monitoring of rodents and rabbits (2014). FELASA recommendations for the health monitoring of mouse, rat, hamster, guinea pig and rabbit colonies in breeding and experimental units. Lab. Anim. 48, 178-192.

56. Pasciuto, E., Burton, O.T., Roca, C.P., Lagou, V., Rajan, W.D., Theys, T., Mancuso, R., Tito, R.Y., Kouser, L., Callaerts-Vegh, Z., et al. (2020). Microglia Require CD4 T Cells to Complete the Fetal-to-Adult Transition. Cell 182, 625-640. 


\section{STAR $\star$ METHODS}

\section{KEY RESOURCES TABLE}

\begin{tabular}{|c|c|c|}
\hline REAGENT or RESOURCE & SOURCE & IDENTIFIER \\
\hline \multicolumn{3}{|l|}{ Antibodies } \\
\hline 2.4G2 Fc Block & ATCC & ATCC $\circledast$ HB-197; RRID: CVCL_9148 \\
\hline \multirow[t]{2}{*}{ Alexa Fluor ${ }^{\circledR} 647$ anti-mouse CD64 } & $\mathrm{BD}$ & Cat \#558539; RRID: AB_647120 \\
\hline & & Clone \#X54-5/7.1 \\
\hline \multirow[t]{2}{*}{ Alexa Fluor $\AA^{700}$ anti-mouse MHC-II } & eBioscience & Cat \#56-5321-82; RRID: AB_494009 \\
\hline & & Clone \#M5/114.15.2 \\
\hline \multirow[t]{2}{*}{ APC eFluor780 anti-mouse CD11c } & eBioscience & Cat \#47-0114-82; RRID: AB_1548652 \\
\hline & & Clone \#N418 \\
\hline \multirow[t]{2}{*}{ Brilliant Violet 510 anti-mouse CD86 } & $\mathrm{BD}$ & Cat \#563077; RRID: AB_2737991 \\
\hline & & Clone \#GL1 \\
\hline \multirow[t]{2}{*}{ Brilliant Violet 605 anti-mouse CD24 } & BioLegend & Cat \#101827; RRID: AB_2563464 \\
\hline & & Clone \#M1/69 \\
\hline \multirow[t]{2}{*}{ Brilliant Violet 650 anti-mouse XCR1 } & BioLegend & Cat \#148220; RRID: AB_2566410 \\
\hline & & Clone \#ZET \\
\hline \multirow[t]{2}{*}{ Brilliant Violet 785 anti-mouse/human CD45R/B220 } & BioLegend & Cat \#103246; RRID: AB_2563256 \\
\hline & & Clone \#RA3-6B2 \\
\hline \multirow[t]{2}{*}{ PerCP-eFluor 710 anti-mouse CD172a (SIRPa) } & eBioscience & Cat \#46-1721-82; RRID: AB_10804639 \\
\hline & & Clone \#P84 \\
\hline \multirow[t]{2}{*}{$\mathrm{PE}$ anti-mouse $\mathrm{F} 4 / 80$} & BioLegend & Cat \#123110; RRID: AB_893486 \\
\hline & & Clone \#BM8 \\
\hline \multirow[t]{2}{*}{ PE-594 anti-mouse CD11b } & $\mathrm{BD}$ & Cat \#562287; RRID: AB_11154216 \\
\hline & & Clone \#M1/70 \\
\hline \multirow[t]{2}{*}{ PE-Cyanine7 anti-mouse CD40 } & BioLegend & Cat \#124622; RRID: AB_10897812 \\
\hline & & Clone \#3/23 \\
\hline \multirow[t]{2}{*}{ BUV395 Hamster anti-mouse CD3 } & $\mathrm{BD}$ & Cat \#563565; RRID: AB_2738278 \\
\hline & & Clone \#145-2C11 \\
\hline \multirow[t]{2}{*}{ BUV395 Rat anti-mouse CD19 } & $\mathrm{BD}$ & Cat \#565965; RRID: AB_2739418 \\
\hline & & Clone \#103 \\
\hline \multirow[t]{3}{*}{ Brilliant Violet 785 anti-mouse CD138 (Syndecan-1) Antibody } & BioLegend & Cat \#142534; RRID: AB_2814047 \\
\hline & & Clone\#281-2 \\
\hline & & Lot\# B291924 \\
\hline \multirow[t]{3}{*}{ IgM Monoclonal Antibody } & eBioscience & Cat \#14-5790-85; RRID: AB_467583 \\
\hline & & Clone\#II/41 \\
\hline & & Lot\#2213349 \\
\hline \multirow[t]{2}{*}{ InvitrogenAlexa Fluor 532 Antibody Labeling Kit } & Thermofisher Scientific & Cat \#A20182; RRID: AB_2736944 \\
\hline & & Lot\#20063164 \\
\hline \multirow{3}{*}{$\begin{array}{l}\text { CD45R (B220) Monoclonal Antibody (RA3-6B2), PerCP-eFluor 710, } \\
\text { eBioscience }\end{array}$} & Invitrogen & Cat \#46-0452-82; RRID: AB_10717389 \\
\hline & & Clone\#RA3-6B2 \\
\hline & & Lot\# 2065656 \\
\hline \multirow[t]{3}{*}{ BB790-P Hamster Anti-Mouse TCR $\beta$ Chain } & $\mathrm{BD}$ & Cat \#624296; RRID: AB_394679 \\
\hline & & Clone\#H57-597 \\
\hline & & Lot\# 8038906 \\
\hline \multirow[t]{3}{*}{ PE anti-mouse CD184 (CXCR4) Antibody } & BioLegend & Cat \#146506; RRID: AB_2562783 \\
\hline & & Clone\#L276F12 \\
\hline & & Lot\# B242855 \\
\hline \multirow[t]{3}{*}{ Alexa Fluor® 594 anti-T-bet Antibody } & BioLegend & Cat \#644834; RRID: AB_2728474 \\
\hline & & Clone\#4B10 \\
\hline & & Lot\# B305816 \\
\hline \multirow[t]{3}{*}{ Gata-3 Monoclonal Antibody (TWAJ), PE-eFluor 610, eBioscience } & Invitrogen & Cat \#61-9966-42; RRID: AB_2574686 \\
\hline & & Clone\#TWAJ \\
\hline & & Lot\# 2050432 \\
\hline
\end{tabular}


Please cite this article in press as: Silva-Cayetano et al., A Booster Dose Enhances Immunogenicity of the COVID-19 Vaccine Candidate ChAdOx1 nCoV-19 in Aged Mice, Med (2020), https://doi.org/10.1016/j.medj.2020.12.006

CellPress

OPEN ACCESS

\section{Clinical and Translational Article}

\begin{tabular}{|c|c|c|}
\hline \multicolumn{3}{|l|}{ Continued } \\
\hline REAGENT or RESOURCE & SOURCE & IDENTIFIER \\
\hline \multirow[t]{3}{*}{ CD69 Monoclonal Antibody (H1.2F3), PE-Cyanine5, eBioscience } & \multirow[t]{3}{*}{ Invitrogen } & Cat \#15-0691-82; RRID: AB_468772 \\
\hline & & Clone\#H1.2F3 \\
\hline & & Lot\# 2161997 \\
\hline \multirow[t]{3}{*}{ FOXP3 Monoclonal Antibody (FJK-16 s), PE-Cyanine5.5, eBioscience } & \multirow[t]{3}{*}{ Invitrogen } & Cat \#35-5773-82; RRID: AB_11218094 \\
\hline & & Clone\#FJK-16 s \\
\hline & & Lot\# 2160553 \\
\hline \multirow{3}{*}{$\begin{array}{l}\text { PE/Cyanine7 anti-mouse/human GL7 Antigen ( } T \text { and B cell Activation } \\
\text { Marker) Antibody }\end{array}$} & \multirow[t]{3}{*}{ BioLegend } & Cat \#144620; RRID: AB_2800677 \\
\hline & & Clone\#GL7 \\
\hline & & Lot\# B308239 \\
\hline \multirow[t]{3}{*}{ Bcl-6 Antibody, anti-human/mouse, REAfinity } & \multirow[t]{3}{*}{ Miltenyi Biotec } & Cat \#130-121-997; RRID: AB_2801823 \\
\hline & & Clone\#REA373 \\
\hline & & Lot\# 5200701434 \\
\hline \multirow[t]{3}{*}{ Alexa Fluor ${ }^{\circledR} 700$ anti-mouse Ki-67 Antibody } & \multirow[t]{3}{*}{ BioLegend } & Cat \#652420; RRID: AB_2564285 \\
\hline & & Clone\#16A8 \\
\hline & & Lot\# B279993 \\
\hline \multirow[t]{2}{*}{ Mouse IgG Isotype control } & \multirow[t]{2}{*}{ Invitrogen } & Cat \#10400C; RRID: AB_2532980 \\
\hline & & Lot\#286589 \\
\hline \multirow[t]{2}{*}{ Rat IgG Isotype control } & \multirow[t]{2}{*}{ Invitrogen } & Cat \#10700; RRID: AB_2610661 \\
\hline & & Lot\#UD287160 \\
\hline \multirow[t]{3}{*}{ CD16/CD32 Monoclonal Antibody (93), eBioscience } & \multirow[t]{3}{*}{ Invitrogen } & Cat \#14-0161-82; RRID: AB_467133 \\
\hline & & Clone\#93 \\
\hline & & Lot\#2083493 \\
\hline \multirow[t]{3}{*}{ BUV395 Rat Anti-Mouse IL-17A } & \multirow[t]{3}{*}{$\mathrm{BD}$} & Cat \#565246; RRID: AB_2722575 \\
\hline & & Clone\#TC11-18H10 \\
\hline & & Lot\#8113640 \\
\hline \multirow[t]{3}{*}{ BUV496 Rat Anti-Mouse CD4 } & $\mathrm{BD}$ & Cat \#612952; RRID: AB_2813886 \\
\hline & & Clone\#GK1.5 \\
\hline & & Lot\#0080998 \\
\hline BUV737 Rat Anti-Mouse IFN- $\gamma$ & $\mathrm{BD}$ & Cat \#612769; RRID: AB_2870098 \\
\hline & & Clone\#XMG1.2 \\
\hline & & Lot\#9205652 \\
\hline Brilliant Violet 421 anti-mouse TNF- $\alpha$ Antibody & BioLegend & Cat \#506328; RRID: AB_2562902 \\
\hline & & Clone\#MP6-XT22 \\
\hline & & Lot\#B293819 \\
\hline Granzyme B Monoclonal Antibody (NGZB), eFluor 450, eBioscience & eBioscience & Cat \#48-8898-82; RRID: AB_11149362 \\
\hline & & Clone\#NGZB \\
\hline & & Lot\#E15759-103 \\
\hline Brilliant Violet 570 anti-mouse CD3 Antibody & BioLegend & Cat \#100225; RRID: AB_10900444 \\
\hline & & Clone\#17A2 \\
\hline & & Lot\#B301598 \\
\hline Biotin anti-mouse CD154 Antibody & BioLegend & Cat \#106503; RRID: AB_313268 \\
\hline & & Clone\#MR1 \\
\hline & & Lot\#B297322 \\
\hline Brilliant Violet 605 Streptavidin & BioLegend & Cat \#405229 \\
\hline & & Lot\#B267737 \\
\hline BV650 Rat Anti-Mouse IL-10 & $\mathrm{BD}$ & Cat \#564083; RRID: AB_2738583 \\
\hline & & Clone\#JES5-16E3 \\
\hline & & Lot\#9161567 \\
\hline Brilliant Violet 711 anti-mouse IL-4 Antibody & BioLegend & Cat \#504133; RRID: AB_2565950 \\
\hline & & Clone\#11B11 \\
\hline BV750 Rat Anti-CD11b & $\mathrm{BD}$ & Cat \#624380; RRID: AB_2871704 \\
\hline & & Clone\#M1/70 \\
\hline & & Lot\#8038933 \\
\hline
\end{tabular}




\section{Clinical and Translational Article}

\begin{tabular}{|c|c|c|}
\hline \multicolumn{3}{|l|}{ Continued } \\
\hline REAGENT or RESOURCE & SOURCE & IDENTIFIER \\
\hline \multirow{3}{*}{$\begin{array}{l}\text { CD19 Monoclonal Antibody (eBio1D3 (1D3)), Super Bright 780, } \\
\text { eBioscience }\end{array}$} & \multirow[t]{3}{*}{ Invitrogen } & Cat \#78-0193-82; RRID: AB_2722936 \\
\hline & & Clone\#eBio1D3 \\
\hline & & Lot\#2200038 \\
\hline \multirow[t]{2}{*}{ IL-13 Monoclonal Antibody (eBio13A), Alexa Fluor 488, eBioscience } & \multirow[t]{2}{*}{ Invitrogen } & Cat \# 53-7133-82; RRID: AB_2016708 \\
\hline & & Clone\#eBio13A \\
\hline \multirow[t]{3}{*}{ IL-6 Monoclonal Antibody (MP5-20F3), PerCP-eFluor 710, eBioscience } & \multirow[t]{3}{*}{ Invitrogen } & Cat \#46-7061-82; RRID: AB_2573829 \\
\hline & & Clone\#MP5-20F3 \\
\hline & & Lot\#E20156-102 \\
\hline \multirow[t]{3}{*}{ Perforin Rat anti-Mouse, PE, Clone: eBioOMAK-D, eBioscience } & \multirow[t]{3}{*}{ Invitrogen } & Cat \#12-9392-82; RRID: AB_466243 \\
\hline & & Clone\#eBioOMAK-D \\
\hline & & Lot\#1988475 \\
\hline \multirow[t]{3}{*}{ PE/Dazzle 594 anti-mouse IL-2 Antibody } & \multirow[t]{3}{*}{ BioLegend } & Cat \#503840; RRID: AB_2566724 \\
\hline & & Clone\#JES6-5H4 \\
\hline & & Lot\#B253794 \\
\hline \multirow{3}{*}{$\begin{array}{l}\text { TCR gamma/delta Monoclonal Antibody (eBioGL3 (GL-3, GL3)), PE- } \\
\text { Cyanine5, eBioscience }\end{array}$} & \multirow[t]{3}{*}{ Invitrogen } & Cat \# 15-5711-83; RRID: AB_468804 \\
\hline & & Clone\#eBioGL3 \\
\hline & & Lot\#1975736 \\
\hline \multirow[t]{3}{*}{ Purified anti-mouse NK-1.1 Antibody } & \multirow[t]{3}{*}{ BioLegend } & Cat \#108702; RRID: AB_313389 \\
\hline & & Clone\#PK136 \\
\hline & & Lot\#B255763igd \\
\hline PE/Cy5.5 ${ }^{\circledR}$ Conjugation Kit - Lightning-Link ${ }^{\circledR}$ & Abcam & Cat \#ab102899 \\
\hline \multirow[t]{3}{*}{ PE-Vio770-pro-IL-1-beta } & \multirow[t]{3}{*}{ Miltenyi Biotec } & Cat\#130-109-043; RRID: AB_2652405 \\
\hline & & Clone\# \\
\hline & & Lot\#5180628359 \\
\hline \multirow[t]{3}{*}{ eFluor660-IL-21 } & \multirow[t]{3}{*}{ Invitrogen } & Cat \#50-7211-82; RRID: AB_10596796 \\
\hline & & Clone\#FFA21 \\
\hline & & Lot\#1919532 \\
\hline \multirow[t]{3}{*}{ APC-Foxp3 } & \multirow[t]{3}{*}{ Invitrogen } & Cat \# 17-5773-82; RRID: AB_469457 \\
\hline & & Clone\#FJK-16 s \\
\hline & & Lot\#1984797 \\
\hline APC-Foxp3 & Miltenyi Biotec & Cat \#130-111-601; RRID: AB_2651768 \\
\hline & & Clone\#REA788 \\
\hline & & Lot\#5191126192 \\
\hline AF700-IL-5 & R\&D Systems & Cat \#IC405N-100UG; RRID: AB_2233882 \\
\hline & & Clone\#TRFK5 \\
\hline & & Lot\#1581417 \\
\hline eBioscience Fixable Viability Dye eFluor 780 & Invitrogen & Cat \#65-0865-14 \\
\hline & & Lot\#2143361 \\
\hline Alexa Fluor ${ }^{\circledR} 647$ rat anti-mouse lgD & BioLegend & Cat \#405708; RRID: AB_893528 \\
\hline & & Clone $11-26$ c.2a \\
\hline FITC rat anti-mouse Ki67 & Invitrogen & Cat \#11-5698-82; RRID: AB_11151330 \\
\hline & & Clone SolA15 \\
\hline Biotin rat anti-mouse CD21/35 & Thermofisher Scientific & Cat \#14-0211-81; RRID: AB_467154 \\
\hline & & Clone 8D9 \\
\hline Hamster anti-mouse $\mathrm{CD} 3 \varepsilon$ & Thermofisher Scientific & Cat \#14-0033-82; RRID: AB_837128 \\
\hline & & Clone500A2 \\
\hline AF568 goat anti-hamster $\lg G(\mathrm{H}+\mathrm{L})$ & Thermofisher Scientific & Cat \#A-21112; RRID: AB_2535761 \\
\hline BV421 Streptavidin & BioLegend & Cat \#405225 \\
\hline Goat Anti-Mouse IgG- Alkaline Phosphatase conjugate & Sigma-Aldrich & Cat \#AP124A; RRID: AB_11212223 \\
\hline & & Lot\# SLBK6489V \\
\hline Goat Anti-Mouse IgM mu chain (Alkaline Phosphatase) & Abcam & Cat \#ab97227; RRID: AB_10688257 \\
\hline & & Lot\#GR3304914-1 \\
\hline
\end{tabular}




\begin{tabular}{|c|c|c|}
\hline \multicolumn{3}{|l|}{ Continued } \\
\hline REAGENT or RESOURCE & SOURCE & IDENTIFIER \\
\hline Goat Anti-Mouse IgA ( $\alpha$-chain specific)-Alkaline Phosphatase & Sigma-Aldrich & Cat \#A4937; RRID: AB_258210 \\
\hline \multirow[t]{2}{*}{ Goat anti-mouse IgG1-Alkaline Phosphatase } & Southern Biotech & Cat \#1071-04; RRID: AB_2794425 \\
\hline & & Lot\# B5312-YH67C \\
\hline \multirow[t]{2}{*}{ Goat anti-mouse IgG2a-Alkaline Phosphatase } & Southern Biotech & Cat \#1081-04; RRID: AB_2794494 \\
\hline & & Lot\# B4117-RC97F \\
\hline \multirow[t]{2}{*}{ Goat Anti-mouse IgG2b-Alkaline Phosphatase } & Southern Biotech & Cat \#1091-04; RRID: AB_2794541 \\
\hline & & Lot\#J111-SG78 \\
\hline \multirow[t]{2}{*}{ Goat anti-mouse IgG2c-Alkaline Phosphatase } & Southern Biotech & Cat \#1078-04; RRID: AB_2794461 \\
\hline & & Lot\#L3913-R776G \\
\hline \multirow[t]{2}{*}{ Goat anti-mouse IgG3-Alkaline Phosphatase } & Abcam & Cat \#ab98705; RRID: AB_10674160 \\
\hline & & Lot\#GR3211361-1 \\
\hline \multicolumn{3}{|l|}{ Bacterial and Virus Strains } \\
\hline ChAdOx1 nCoV-19 & In house & $\begin{array}{l}\text { Van Doremalan Nature volume 586, } \\
\text { pages578-582(2020) }\end{array}$ \\
\hline \multicolumn{3}{|l|}{ Chemicals, Peptides, and Recombinant Proteins } \\
\hline Yellow-green fluorescent Carboxylate-modified microspheres & Invitrogen & Cat\#F8787 \\
\hline FoxP3/Transcription Factor Staining buffer & eBioscience & Cat\#00-5323-00 \\
\hline Permeabilisation buffer & eBioscience & Cat\#00-8333-56 \\
\hline SARS-CoV-2 spike protein immunodominant domain peptides & Miltenyi Biotec & Cat\#130-126-700 \\
\hline Phorbol 12,13 dibutyrate & Tocris Bioscience & Cat\#4153/1 \\
\hline Ionomycin calcium salt & Tocris Bioscience & Cat\# 1704/1 \\
\hline Brefeldin A & Tocris Bioscience & Cat\# 1231/5 \\
\hline Collagenase D & Roche & Cat\#11088866001 \\
\hline Live/Dead fixable Blue Dead Cell Staining & Invitrogen & Cat\#L23105 \\
\hline Brilliant Stain buffer & BD Bioscience & Cat\#563794; RRID: AB_2869750 \\
\hline UltraComp eBeads & Invitrogen & Cat\#01-2222-41 \\
\hline Paraformaldehyde & Sigma-Aldrich & Cat\#P6148 \\
\hline L-Lysine & Sigma-Aldrich & Cat\#L5501 \\
\hline $\mathrm{Na} 3 \mathrm{PO} 4$ & Sigma-Aldrich & Cat\#342483 \\
\hline $\mathrm{NalO} 4$ & Sigma-Aldrich & Cat\#210048 \\
\hline Sucrose & Sigma-Aldrich & Cat\#S0389 \\
\hline Optimum Cutting Temperature (OCT) medium & VWR & Cat\#25608-930 \\
\hline DAPI & Invitrogen & Cat\#D1306 \\
\hline Triton $\mathrm{X}$ & Sigma-Aldrich & Cat\#X100 \\
\hline Hydromount mounting medium & National Diagnostics & Cat\#HS-106 \\
\hline TRIzol reagent & ThermoFisher Scientific & Cat\#15596026 \\
\hline PEI transfection reagent & Sigma-Aldrich & Cat\# 408727 \\
\hline SARS-CoV-2 FL-S protein & In house & $\begin{array}{l}\text { Graham et al., npj Vaccines volume } 5 \text {, } \\
\text { Article number: } 69 \text { (2020) }\end{array}$ \\
\hline Blocker Casein & Thermo Fisher Scientific & Cat\# 37528 \\
\hline p-Nitrophenyl Phosphate Substrate Buffer & Sigma-Aldrich & Cat\# 487664 \\
\hline BrightGlo luciferase reagent & Promega & Cat\# E2650 \\
\hline TransIT X2 transfection reagent & Geneflow & Cat\# E7-0178 \\
\hline \multicolumn{3}{|l|}{ Critical Commercial Assays } \\
\hline BD cytofix/cytoperm & $\mathrm{BD}$ & Cat\#554722; RRID: AB_2869008 \\
\hline TaqManRNA to Ct 1-step kit & ThermoFisher Scientific & Cat\#4392656 \\
\hline \multirow[t]{3}{*}{ TaqMan gene expression assay } & ThermoFisher Scientific & Mx1 Mm00487796_m1 \\
\hline & & Gbp2 Mm00494576_g1 \\
\hline & & Hprt Mm03024075_m1 \\
\hline \multicolumn{3}{|l|}{ Experimental Models: Cell Lines } \\
\hline HEK293T & ATCC & ATCC® CRL-3216; RRID:CVCL_0063 \\
\hline \multicolumn{3}{|l|}{ Experimental Models: Organisms/Strains } \\
\hline Mouse C57BL/6Babr & Babraham Institute & C57BL/6 $6^{\mathrm{Babr}}$ \\
\hline
\end{tabular}




\begin{tabular}{|c|c|c|}
\hline \multicolumn{3}{|l|}{ Continued } \\
\hline REAGENT or RESOURCE & SOURCE & IDENTIFIER \\
\hline \multicolumn{3}{|l|}{ Recombinant DNA } \\
\hline SARS-CoV-2 Spike & BioBasic & Wuhan strain QHR63290.2 \\
\hline pcDNA3.1 & Invitrogen & Cat\# V79020 \\
\hline Human Angiotensin-converting enzyme 2 (ACE2) expression plasmid & Addgene & Plasmid\#1786; RRID:Addgene_1786 \\
\hline \multicolumn{3}{|l|}{ Software and Algorithms } \\
\hline FlowJo & Treestar & https://www.flowjo.com/; RRID: SCR_008520 \\
\hline Volocity & PerkinElmer & $\begin{array}{l}\text { https://www.perkinelmer.com:443/ } \\
\text { category/image-analysis-software; RRID: SCR_002668 }\end{array}$ \\
\hline Glomax-Multi detection system & Promega & TM297, Cat\#E7081; RRID: SCR_015575 \\
\hline GraphPad Prism & GraphPad & https://www.graphpad.com/; RRID: SCR_002798 \\
\hline CFX Manager software & BioRad & CFX Manager Software \#1845000; RRID: SCR_017251 \\
\hline SOFTmax PRO & Molecular Devices & $\begin{array}{l}\text { https://www.moleculardevices.com/ } \\
\text { products/microplate-readers/; RRID: SCR_014240 }\end{array}$ \\
\hline $\mathrm{R}$ & & https://www.r-project.org; RRID: SCR_001905 \\
\hline \multicolumn{3}{|l|}{ Other } \\
\hline Breeder and Grower CRM(P)VP diet & Special diet services & Cat\# 801722 \\
\hline
\end{tabular}

\section{RESOURCE AVAILABILITY}

\section{Lead Contact}

Further information and requests for resources and reagents should be directed to and will be fulfilled by the Lead Contact, Michelle Linterman (michelle.linterman@ babraham.ac.uk).

\section{Materials Availability}

This project did not generate new unique reagents.

\section{Data and Code Availability}

This project did not generate any new code or novel datasets.

\section{EXPERIMENTAL MODEL AND SUBJECT DETAIL}

Mouse housing and husbandry

C57BL/6Babr mice were bred, aged and maintained in the Babraham Institute Biological Support Unit. No primary pathogens or additional agents listed in the Federation of European Laboratory Animal Science Association recommendations ${ }^{55}$ were detected during health monitoring surveys of the stock holding rooms. Ambient temperature was $\sim 19-21^{\circ} \mathrm{C}$ and relative humidity $52 \%$. Lighting was provided on a $12 \mathrm{hr}$ light: $12 \mathrm{hr}$ dark cycle including $15 \mathrm{~min}$ 'dawn' and 'dusk' periods of subdued lighting. After weaning, mice were transferred to individually ventilated cages with 1-5 mice per cage. Mice were fed Mouse Breeder and Grower CRM (P) VP diet (Special Diet Services) ad libitum and received seeds (e.g., sunflower, millet) at the time of cage-cleaning as part of their environmental enrichment. All mouse experimentation was approved by the Babraham Institute Animal Welfare and Ethical Review Body. Animal husbandry and experimentation complied with existing European Union and United Kingdom Home Office legislation and local standards (PPL: P4D4AF812). Young mice were 1012 weeks old, and aged mice 93-96 weeks old when experiments were started. Mice that had tumors, which can occur in aged mice, were excluded from the analysis.

\section{METHODS DETAILS}

\section{Immunisation and tissue sampling}

Mice were immunized in the right quadriceps femoris muscle with $50 \mu \mathrm{L}$ of either $1 \times 10^{8}$ infectious units of ChAdOx1 nCoV-19 in phosphate buffered saline (PBS) 


\section{CellPress}

alone, $50 \mu \mathrm{L} 0.02 \mu \mathrm{m}$ yellow-green fluorescent Carboxylate-Modified Microspheres (Invitrogen \# F8787) in phosphate buffered saline (0.5\% solids, final injected concentration). At the indicated time points post vaccination, blood, the right medial iliac lymph node, spleen and right quadriceps femoris muscle were taken for analysis.

\section{Flow cytometry}

For $T$ and $B$ cell flow cytometric stains a single cell suspension was prepared from the iliac lymph node and half the spleen was generated by pressing the tissues through a $70 \mu \mathrm{m}$ mesh in $2 \%$ FBS in PBS. Cell numbers and viability were determined using a CASY TT Cell Counter (Roche). $2 \times 10^{6}$ cells were transferred to 96-well plates for antibody staining. Samples were blocked with $100 \mu \mathrm{L}$ of $2.4 \mathrm{G} 2$ Fc Block (made in house) for $20 \mathrm{~min}$ at $4^{\circ} \mathrm{C}$. Cells were then stained with surface antibody mix for $2 \mathrm{hrs}$ at $4^{\circ} \mathrm{C}$ and then were fixed with the eBiosciences Foxp3/Transcription Factor Staining Buffer (\#00-5323-00) for $30 \mathrm{~min}$ at $4^{\circ} \mathrm{C}$. Cells were then washed with $1 \times$ Permeabilisation buffer (eBioscience \#00-8333-56) twice and stained with intracellular antibody mix in $1 \times$ Permeabilisation buffer at $4{ }^{\circ} \mathrm{C}$ overnight. For cytokine staining, splenic cells were stimulated with a pool of SARS-CoV-2 spike protein immunodominant domain peptides, (Miltenyi Biotec \#130-126-700) at a 0.6 $\mu \mathrm{M}$ concentration (approx. $1 \mu \mathrm{g} / \mathrm{ml}$ ), while lymph node cells were stimulated with $0.5 \mu \mathrm{g} / \mathrm{ml}$ of Phorbol 12,13 dibutyrate $(\mathrm{PdBu}$, Tocris Bioscience, \#), $0.75 \mu \mathrm{g} / \mathrm{ml}$ of Ionomycin calcium salt (Tocris Bioscience, \#), both in warm complete RPMI (10\% FCS, 1\% Pen/Strep, 1\% glutamine, $1 \%$ sodium pyruvate, $1 \%$ MEM NAA, $1 \%$ HEPES and $55 \mu \mathrm{M}$-2-mercaptoethanol) for $4 \mathrm{hrs}$ at $37^{\circ} \mathrm{C}, 5 \% \mathrm{CO} 2$. Cytokine secretion was then blocked with $22 \mu \mathrm{g} / \mathrm{ml}$ of Brefeldin A (Tocris Bioscience, \#) in warm complete RPMI for $2 \mathrm{hrs}$ at $37^{\circ} \mathrm{C}, 5 \%$ $\mathrm{CO} 2$. The cells were then stained with surface antibody mix for 20 minutes at $4^{\circ} \mathrm{C}$ and were subsequently fixed with $2 \%$ formaldehyde for $30 \mathrm{~min}$ at room temperature. After two wash steps with 1x Permeabilisation buffer (eBioscience \#00-8333-56), the cells were stained with intracellular antibody mix in 1x Permeabilisation buffer, supplemented with $20 \% 2.4 \mathrm{G} 2 \mathrm{Fc}$ Block at $4{ }^{\circ} \mathrm{C}$ overnight. Following overnight staining, samples were washed twice with $1 \times$ Permeabilisation buffer and once with $2 \%$ FBS in PBS and acquired on a Cytek ${ }^{\mathrm{TM}}$ Aurora. Cells for single color controls were prepared in the same manner as the fully stained samples. The antibodies used for surface and overnight staining are listed in the Key Resources Table.

Manual gating of flow cytometry data was done using FlowJo v10 software (Tree Star). tSNE, FlowSOM and heatmap analysis were performed on iLN samples from day 7 post-vaccination using $R$ (version 4.0.2) using code that has previously been described $^{56}$. The antibodies used for surface staining are listed in Key Resources Table.

\section{Confocal imaging}

For imaging of germinal centers, half of the spleen was fixed in periodate-lysineparaformaldehyde (PLP) containing 1\% (v/v) PFA (Sigma \#P6148), 0.075 M L-Lysine (Sigma \#L5501), 0.37 M Na3PO4 (pH 7.4) (Sigma \#342483) and 0.01 M NaIO4 (Sigma \#210048), for $4 \mathrm{hr}$ at $4^{\circ} \mathrm{C}$. For imaging yellow-green fluorescent Carboxylate-Modified Microspheres (Invitrogen \# F8787), lymph nodes and spleen were fixed in BD Cytofix/Cytoperm (BD Cat \#554722), diluted 1 in 4 in PBS. After fixation, all tissues were dehydrated in 30\% sucrose (Sigma \#S0389) overnight, embedded in Optimum Cutting Temperature (OCT) medium (VWR \#25608-930) on dry ice and stored at $-80^{\circ} \mathrm{C}$. The frozen tissues were cut into $10 \mu \mathrm{m}$ sections using a cryostat (Leica Biosystems) at $-20^{\circ} \mathrm{C}$ and again stored at $-80^{\circ} \mathrm{C}$. For imaging yellow-green fluorescent carboxylate-codified microspheres, slides were first air-dried and then washed in PBS three times after which DAPI staining was performed (Invitrogen \#D1306; 
diluted 1:10 000 in PBS) for 10 minutes at room temperature protected from light. Slides were then washed three times with PBS and coverslips were mounted on the slides using Hydromount mounting medium (National Diagnostics \#HS-106). For antibody stains, the slides were first air-dried and then hydrated in $0.5 \%$ Tween 20 in PBS (PBS-T). The slides were blocked in PBS containing 2\% BSA and 10\% goat serum for $2 \mathrm{hrs}$, washed three times with PBS-T and then permeabilised with PBS containing 2\% Triton X (Sigma \#X100) for 45min. Following three wash steps with PBS-T, the slides were stained with primary antibody mix, which included AF647-conjugated rat anti-mouse IgD (clone 11-26 c.2a, Biolegend; 1:200), FITC-conjugated rat anti-mouse Ki67 (clone SolA15, Invitrogen; 1:100), rat anti-mouse biotin-conjugated CD21/35 (clone 8D9, ThermoFisher Scientific; 1:400) and hamster anti-mouse CD3 $\varepsilon$ (clone 500A2, ThermoFisher Scientific; 1:200), in PBS-T containing 1\% BSA at $4^{\circ} \mathrm{C}$ overnight. The next day, slides were washed three times with PBS-T and incubated with secondary antibody mix, which included AF568-conjugated goat antihamster lgG (Thermofisher, 1:1000) and BV421-conjugated Streptavidin (Biolegend, $1: 1000)$, in PBS-T containing $2 \%$ goat serum for $2 \mathrm{hr}$ at room temperature. Slides were then washed three times with PBS-T, PBS and $\mathrm{dH}_{2} \mathrm{O}$ and coverslips were mounted using Hydromount mounting medium (National Diagnostics \#HS-106). Images were acquired using a Zeiss 780 confocal microscope with $10 x$ and $20 x$ objectives and analyzed using ImageJ.

\section{Enzyme-linked immunosorbent assay (ELISA)}

Standardized ELISA was performed to detect SARS-CoV-2 FL-S protein - specific antibodies in sera. MaxiSorp plates (Nunc) were coated with 100 or 250 ng/well FL-S protein overnight at $4{ }^{\circ} \mathrm{C}$ for detection of $\lg \mathrm{g}$ or $\lg \mathrm{M}$ and $\lg \mathrm{A}$, respectively, prior to washing in PBS/Tween $(0.05 \% \mathrm{v} / \mathrm{v})$ and blocking with Blocker Casein in PBS (Thermo Fisher Scientific) for $1 \mathrm{~h}$ at room temperature (RT). Standard positive serum (pool of mouse serum with high endpoint titer against FL-S protein), individual mouse serum samples, negative and an internal control (diluted in casein) were incubated for 2 hours at room temperature for detection of specific $\lg G$ or $1 \mathrm{~h}$ at $37^{\circ} \mathrm{C}$ for detection of specific IgM or IgA. Following washing, bound antibodies were detected by addition of alkaline phosphatase (AP)-conjugated goat anti-mouse lgG (Sigma-Aldrich) for $1 \mathrm{~h}$ at room temperature or addition of AP-conjugated goat anti-mouse IgM or IgA (Abcam and Sigma-Aldrich, respectively) and addition of p-Nitrophenyl Phosphate, Disodium Salt substrate (Sigma-Aldrich). An arbitrary number of ELISA units were assigned to the reference pool and optical density values of each dilution were fitted to a 4-parameter logistic curve using SOFTmax PRO software. ELISA units were calculated for each sample using the optical density values of the sample and the parameters of the standard curve.

The IgG subclass ELISA were performed according to the protocol described for detection of specific $\lg M$ or $\lg A$ in the serum. In addition, all serum samples were diluted to 1 total IgG ELISA unit and then detected with anti-mouse IgG subclassspecific secondary antibodies (Southern Biotech or Abcam). The results of the IgG subclass ELISA are presented using optical density values instead of the ELISA units used for the total $\lg$ ELISA. The ratio of $\operatorname{lgG}_{2} / \operatorname{lgG}_{1}$ was calculated for each animal as sum of optical density values $\left(\operatorname{lgG}_{2 b}+\lg _{2 c}\right)$ divided by the optical density value of $\lg _{1}$ and represented as mean values with standard deviation (SD).

\section{Micro neutralisation test using lentiviral-based pseudotypes bearing the SARS-CoV-2 Spike}

Lentiviral-based SARS-CoV-2 pseudotyped viruses were generated in HEK293T cells incubated at $37^{\circ} \mathrm{C}, 5 \% \mathrm{CO}_{2}$ as previously described ${ }^{27}$. Briefly, cells were seeded at a 


\section{CellPress}

density of $7.5 \times 10^{5}$ in 6 well dishes, before being transfected with plasmids as follows: 500 ng of SARS-CoV-2 spike, 600 ng p8.91 (encoding for HIV-1 gag-pol), 600 ng CSFLW (lentivirus backbone expressing a firefly luciferase reporter gene), in Opti-MEM (GIBCO) along with $10 \mu \mathrm{L}$ PEI $(1 \mu \mathrm{g} / \mathrm{mL})$ transfection reagent. A 'no glycoprotein' control was also set up using the pcDNA3.1 vector instead of the SARS-CoV-2 S expressing plasmid. The following day, the transfection mix was replaced with $3 \mathrm{~mL}$ DMEM (Dulbecco's Modified Eagle's medium) with 10\% fetal bovine serum (DMEM-10\%) and incubated for 48 and 72 hours, after which supernatants containing pseudotyped SARS-CoV-2 (SARS-CoV-2 pps) were harvested, pooled and centrifuged at $1,300 \times \mathrm{g}$ for 10 minutes at $4{ }^{\circ} \mathrm{C}$ to remove cellular debris. Target HEK293T cells, previously transfected with 500 ng of a human Angiotensinconverting enzyme 2 (ACE2) expression plasmid (Addgene, Cambridge, MA, USA) were seeded at a density of $2 \times 10^{4}$ in $100 \mu \mathrm{L}$ DMEM-10\% in a white flat-bottomed 96-well plate one day prior to harvesting SARS-CoV-2 pps. The following day, SARSCoV-2 pseudotyped viruses were titrated 10 -fold on target cells, and the remainder stored at $-80^{\circ} \mathrm{C}$. For micro neutralisation tests, mouse sera were diluted 1:20 in serum-free media and $50 \mu \mathrm{L}$ was added to a 96-well plate in triplicate and titrated 2 -fold. A fixed titerd volume of SARS-CoV-2 pseudotyped viruses was added at a dilution equivalent to $10^{5}$ signal luciferase units in $50 \mu \mathrm{L}$ DMEM-10\% and incubated with sera for 1 hour at $37^{\circ} \mathrm{C}, 5 \% \mathrm{CO}_{2}$ (giving a final sera dilution of 1:40). Target cells expressing human ACE2 were then added at a density of $2 \times 10^{4}$ in $100 \mu \mathrm{L}$ and incubated at $37^{\circ} \mathrm{C}, 5 \% \mathrm{CO}_{2}$ for 72 hours. Firefly luciferase activity was then measured with BrightGlo luciferase reagent and a Glomax-Multi ${ }^{+}$Detection System (Promega, Southampton, UK). Pseudovirus neutralization titers were expressed as the reciprocal of the serum dilution that inhibited luciferase expression by $50 \%\left(\mathrm{IC}_{50}\right)$.

\section{QUANTIFICATION AND STATISTICAL ANALYSIS}

All experiments were performed either twice or three times with 3-8 mice per group. Data was first tested for Gaussian distribution using a Shapiro-Wilk test. Then data that was consistent with a normal distribution was analyzed with either a Student's t test for comparing two dataset, or one-way ANOVA test for data with multiple groups. If the data did not follow a normal distribution then a Mann-Whitney test was used for comparing two datasets and a Kruskal Wallis test for multiple comparisons. For ELISA data $p$ values were generated on log transformed data. All $p$ values shown are adjusted for multiple comparisons where multiple tests were performed on the same data. Analyses were performed within the Prism v8 software (GraphPad). 